The

Carl Beck Papers in Russian \&

East European Studies

Number 1003

James Niessen, Editor

Religious Compromise,

Political Salvation

The Greek Catholic Church and

Nation-building in Eastern Europe

John-Paul Himka

James T. Flynn

James Niessen 
James Niessen is a librarian at the University of Texas at Austin. He received his BA from the University of Notre Dame and his $\mathrm{PhD}$ in East European history from Indiana University, where his dissertation, Battling Bishops: Religion and Politics in Transylvania on the Eve of the Ausgleich (1989) was directed by György Ránki. His research in Hungary and Romania was supported by IREX, Lajos Kossuth University in Debrecen, and the Europa Institute in Budapest. His most recent articles are on the establishment of the Hungarian Uniate diocese of Hajdúdorog in 1912 and on the evolution of Romanian nationalism in the twentieth century.

John-Paul Himka is a professor of history at the University of Alberta in Edmonton. He received his $\mathrm{PhD}$ from the University of Michigan in 1977 and is the author of Socialism in Galicia: The Emergence of Polish Social Democracy and Ukrainian Radicalism (1860-1890) (1983) and Galician Villagers and the Ukrainian National Movement in the Nineteenth Century (1988).

James T. Flynn is a professor of history at the College of the Holy Cross. He received his $\mathrm{PhD}$ from Clark University in 1964 . His published studies include The University Reform of Alexander, 1802-1835 (1988).

No.1003, May 1993

- 1993 by The Center for Russian and East European Studies, University of Pittsburgh ISSN 08899-275X

The Carl Beck Papers:

Editors: William Chase, Bob Donnorummo, Ronald H. Linden

Assistant Editors: Mitchell Bjerke, Martha Snodgrass

Cover design: Mike Savitski

Submissions to The Carl Beck Papers are welcome. Manuscripts must be in English, double-spaced throughout, and less than 120 pages in length. Acceptance is based on anonymous review. Mail submissions to: Editor, The Carl Beck Papers, Center for Russian and East European Studies, 4G-21 Forbes Quadrangle, University of Pittsburgh, Pittsburgh, PA 15260. 


\section{Religious Compromise, Political Salvation: The Greek Catholic Church and Nation-building in Eastern Europe}

James Niessen, Editor

Introduction $\ldots \ldots \ldots \ldots \ldots \ldots \ldots$ James Niessen

The Greek Catholic Church and the Ukrainian Nation in Galicia . . . . . . . . . . 7 John-Paul Himka

The Uniate Church in Belorussia:

A Case of Nation-Building? . . . . . . . . . . . 27

James T. Flynn

The Greek Catholic Church and the Romanian Nation in Transylvania . . . . . . . 47 James Niessen 


\section{Introduction}

The transformation of the former Soviet bloc has seen the resurrection of the Greek Catholic or Uniate Churches ${ }^{1}$ of the Ukrainians, Belorussians, and Romanians, each of them ministering to a minority of the titular nation and concentrated in a particular region of the national territory. These churches had been suppressed in 1946-48 (and, in the case of Belorussia, in 1839) by church synods or decree, acts of dubious canonicity. The interests and confessional animus of the Orthodox bishops made possible their manipulation and complicity in these acts. Yet it was the Greek Catholics' contribution to national identity that caused the state to favor their suppression. ${ }^{2}$ Religious and national motives were also present in the loyalty of millions to the illegal churches after their suppression and in their role in the revival of these peoples' national aspirations.

The authors presented the original versions of these studies at the annual convention of the American Association for the Advancement of Slavic Studies in 1990, seeking to answer the question: what is the connection between the Greek Catholic Church and the formation of modern nations in the East European area? A church consists of its bishops and clergy, but ultimately of all its members. Therefore a church is both a group of authorities pursuing their policies and an autonomous framework within which a model society may form. Greek Catholic writers helped formulate the national ideology, but nationbuilding is broader than this. The nation was "formed" through autonomous schools, church teaching, and political activity as well as socioeconomic processes that are beyond the scope of the present studies. Greek Catholic bishops exploited local conditions to serve as national leaders vis à vis three parties: the state, other religions, and other ethnic groups.

The church unions were compromises by which Orthodox bishops conceded one or more of four doctrinal points: papal primacy, the admissibility of unleavened bread in the Eucharist, the existence of purgatory, and the procession of the Holy 
Spirit from the Son as well as the Father-i.e., inclusion of the word filioque in the Nicaean Creed. The bishops hoped, in turn, for military, religious, and economic support against adversaries, some of whom were also opponents of the Roman Catholics (domestic non-Catholics, for example, or foreign enemies). These conditions and motives were present in the model union within Europe, the Council of Florence in 1439, at which the Greeks hoped to gain help against the Turks. Similar motives were at work in the more successful unions within the PolishLithuanian Commonwealth and the Habsburg state between 1596 and 1708. The bishops who entered these unions considered compromise with the West to be necessary in order to save what was truly essential in their faith. ${ }^{3}$ The eastern rite was considered inalienable, but it was unclear whether rite included forms of administration as well as worship. Easterners commonly asserted that eastern liturgy and discipline were both fundamental to their faith.

The union policy of the Habsburg Monarchy nicely complemented the dynasty's dedication to centralization and the Catholic faith. At the time of the First Vatican Council in 1870, more than three quarters of the world's Greek Catholics were subjects of the Monarchy. ${ }^{4}$ Although the Monarchy's Catholics never had a unified hierarchy, the state's Josephinist policies, the existence of a central Greek Catholic seminary in Vienna (in addition to local ones) and the importance of the Apostolic Nuncio in Vienna sometimes approximated the consequence of a unified hierarchy. Some Austrian officials and Greek Catholic churchmen saw the creation of a single hierarchy for the eastern-rite Catholics of the Monarchy as desirable. ${ }^{5}$ The rejection of these plans by the Emperor and Rome was a recognition of ethnic diversity and historical differences among the local churches. Later, when even Viennese officials and Roman congregations recognized the importance of nationalism, it was not difficult for churchmen to place themselves and their institutions in the service of the nation. In effect, religion and nationalism seemed to go together naturally.

Outside the Habsburg Monarchy, two other geographic factors were of decisive importance: the changing political framework, and Rome itself. The Polish- 
Lithuanian Commonwealth was, like the Monarchy, a Catholic state that fostered the Greek Catholic Church among the eastern Slavs for political as well as religious reasons. But our three studies demonstrate the unique importance of Habsburg state policy since the Polish Partitions of the late eighteenth century by showing how predominantly Orthodox states, Russia and Romania, and even the Catholic Polish national state, provided a less favorable context for the Greek Catholics. State policies and the prevailing Russian, Polish, and Romanian national ideologies were hostile to the Uniates. The result was nearly fatal for the Belorussians, a mortal threat for Ukrainians, and a perplexing dilemma for Romanian Uniates living in their own national state. In the twentieth century, the communists, despite different motives, sought to mobilize nationalist hostility toward the Catholics for the consolidation of their rule.

The fall of communism accentuates the importance of the other geographic factor, the Holy See. Many Orthodox bishops and politicians have portrayed the Vatican's current energetic policy toward the region as a form of Polish or religious imperialism, from Moscow to Bosnia. ${ }^{6}$ Now as in the past, Catholics benefit from the existence of an ecclesiastic center substantially beyond the reach of the state, whose institutions and policies toward them are correspondingly significant. The Collegio Greco in Rome housed Greek Catholic seminarians from Eastern Europe and elsewhere from the sixteenth century on, and papal encyclicals in 1755, 1756, 1862, and later sought to assuage Greek Catholics' fears concerning the respect for their rites. The pope created a special section within the Propaganda Congregation for eastern rites in 1862 and raised it to an independent congregation in 1917, also founding in that year an Oriental Institute and in 1929 a separate Russian Institute. Archival holdings in Rome contain a wealth of information on the Greek Catholics that until recently were more accessible than those in their native countries. Students of our topic will therefore benefit from the ongoing description of the Vatican Archives for the RLIN library database. ${ }^{7}$

Finding an appropriate combination of eastern and western identities was a task faced by all nationalists in Europe east of France. Greek Catholicism offered 
East Europeans a suitably complex answer to this dilemma. Inevitably it was a controversial answer, for the East clung to more traditional religious forms while the West promised education and progress, and thus change. ${ }^{8}$ Religious compromise had implications for ethnic as well as spiritual survival. Whether alliance with cleanshaven Austrian, Polish, Hungarian, and Italian priests who brought rosaries and scholarships, or with bearded Russian, Greek, and Serbian ones who advocated fidelity to tradition will satisfy the combination of religious and ethnic motives that inspired the church unions remains the difficult question facing these churches. 


\section{Notes}

1. The terms Greek Catholic and Uniate are used interchangeably in this volume. While some other authors use the latter term in a pejorative sense, this is not our intention.

2. A good comparative survey of the Ukrainian and Romanian churches' suppression is provided in Pedro Ramet, "The Interplay of Religious Policy and Nationalities Policy in the Soviet Union and Eastern Europe," in Ramet, ed., Religion and Nationalism in Soviet and East European Politics (revised and expanded edition: Durham and London, 1989), 10-13.

3. This assessment is shared by Steven Runciman in his account of the Union of Florence in The Great Church in Captivity. A Study of the Patriarchate of Constantinople from the Eve of the Turkish Conquest to the Greek War of Independence (Cambridge, 1968), 104-11, and Helmut Rumpler in "Politik und Kirchenunion in der Habsburgermonarchie, "Österreichische Osthefte 6 (1964), 302-20.

4. Constantin G. Patelos, Vatican I et les évêques uniates. Une étape éclairante de la politique romane à l'égard des orientaux (1867-1870) (Louvain, 1981), 376-77.

Two very informative articles on the Uniate Churches, with helpful bibliographies, are "Unierte Kirchen des Orients," by Berthold Spuler, in Die Religion in Geschichte und Gegenwart. Handwörterbuch für Theologie und Religions-wissenschaft, third (revised) edition (Tübingen, 1962), 6: 1128-36, and "Uniate Churches," by Thomas F. Sable, S.J., in The Encyclopedia of Religion (New York: MacMillan, 1987), 15: 138-41.

The present volume examines the largest of the other Greek Catholic groups in the Monarchy, the Rusyns of Transcarpathia, in the context of the Ukrainian and Romanian churches. Readers are directed to the excellent studies by Paul R. Magocsi, The Shaping of a National Identity: Subcarpathian Rus', 1848-1948(Cambridge, Mass., 1978), and "Religion and Identity in the Carpathians, "Cross Currents 7 (1988), 87-107. These works examine the Slovak and Hungarian Greek Catholics living in the Carpathian region as well as Rusyns, but not the Romanians. 
5. Such proposals were made by General András Hadik in 1774, Bishop Leo Sheptycky in 1779, and Father Hippolyt Terlecki in 1860. See Emanuel Turczynski, "Orthodoxe und Unierte," in Die Habsburgermonarchie, IV, Die Konfessionen (Vienna, 1985), 418, and Edith Saurer, "Die Kurie und die Griechisch-Unierten im 19. Jahrhundert," Bericht über den zehnten österreichischen Historikertag in Graz (Vienna, 1970), 81-7.

6. On Ukrainian Greek Catholics' rivalry with both Poles and Orthodox today, see "The Second "Lung"," The Catholic World Report, August, 1992, 26-9. An American priest, Fr. Alexander F.C. Webster, has condemned recent immoderate Orthodox statements: "Without a Vision, " American Orthodoxy (Winter, 1992), 1-4.

7. When completed, the record will provide subject search capability, bibliographies of previous research, and detailed description of individual archival series. See Francis X. Blouin, Jr., "A Case for Bridging the Gap: The Significance of the Vatican Archives Project for International Archival Information Exchange," and Elizabeth Yakel, "Pushing MARC AMC to Its Limits: The Vatican Archives Project," The American Archivist 55 (Winter, 1992), 182-201. Regretably, it appears that the archives of the congregations, of which Propaganda Fidei and Extraordinary Church Affairs have special relevance for the Greek Catholics, will not be included in this record.

8. Józef Chlebowczyk, On Small and Young Nations in Europe. Nation-Forming Processes in Ethnic Borderlands in East-Central Europe (Wroclaw, 1980), 5. 


\section{The Greek Catholic Church and the Ukrainian Nation in Galicia}

\section{John-Paul Himka}

This essay surveys the history of the Ukrainian Uniate (Greek Catholic) Church in Galicia in relation to the politics of nation-building and nationalism and then offers some interpretive, comparative reflections on the specific role of Uniatism in national politics. ${ }^{1}$ Galicia is a region in Western Ukraine roughly corresponding to the oblasts of Lviv, Ternopil and Ivano-Frankivsk in the former Ukrainian SSR. It also extended into what is now Poland; Przemyśl [Peremyshl] in eastern Poland, was the seat of a Greek Catholic eparchy. It has a complicated history of changing state administrations. Since the mid-eighteenth century it has experienced Polish, Austrian, Russian, Ukrainian, Soviet and German rule. The church under consideration is known by several names, including the Uniate and the Ukrainian Catholic Church. I generally prefer the usage of the crucially formative Austrian period (1772-1918), when Empress Maria Theresa named it the Greek Catholic Church in 1774 to underscore its equality with the Roman Catholic Church. ${ }^{2}$ The Ukrainians of Galicia also underwent a change in name; until the early twentieth century, they generally referred to themselves as Ruthenians (rusyny, Ruthenen).

Although the Greek Catholic Church contributed much to Ukrainian nation-building, it did so only on a local, "Carpathian" level. By the time that the Ukrainian national revival began in the late eighteenth and early nineteenth centuries, the Uniate Church had been largely suppressed in most of Ukraine, which was then in the Russian empire. None of the figures prominent in the Ukrainian movement in tsarist Ukraine were connected with the Uniate Church. But however local the 
contribution of the Greek Catholic Church, it was not marginal to the development of the Ukrainian national movement. This was because the locality in which it flourished, Galicia, although constituting a relatively small part of Ukrainian ethnographic territory, played a disproportionate role in all-Ukrainian affairs. It is often and justifiably called the Ukrainian Piedmont. The Ukrainian movement here, under the protection of relatively enlightened and later constitutional Austrian rule, had much more freedom to develop than in autocratic Russia. When Ukrainian-language publications were banned in tsarist Russia in 1863 and 1876, Lviv assumed the role of the chief publishing center for all Ukraine. Only in Austrian Ukraine did Ukrainian-language elementary and secondary schools exist. ${ }^{3}$ Although Kiev and the rest of Central-Eastern Ukraine took center stage in the period 1917-30, Galicia again rose to disproportionate prominence in the 1930s as Soviet Ukraine experienced the ravages of Stalinism. Thus although the range of influence of the Greek Catholic Church was limited to only one area of Ukraine, this area was of unusual significance.

The Uniate Church in Ukraine (and Belorussia) was the product of the Union of Brest, 1596. To raise the status and bring order into the affairs of their church, the Orthodox bishops of the eastern, Ukrainian and Belorussian territories of Poland-Lithuania entered upon union with the Roman Catholic Church. The latter had also been promoting the idea of church union; particularly active were Polish Jesuits, preachers of the counter-reformation such as Piotr Skarga, who took up the cause with missionary fervor. The original idea of the Union of Brest was to unite the entire Orthodox Church of Poland-Lithuania with Rome, but this proved impossible to effect. Instead, only partial union was achieved and Orthodoxy survived alongside Uniatism; the churches viewed each other as mortal rivals and Ukraine was racked by religious conflict through the end of the seventeenth century. Ironically, although by the mid-nineteenth century Galicia was to be the strongest bastion of Uniatism on Ukrainian territory, in the century of religious conflict following the Union of Brest, Galicia had been the strongest bastion of Orthodoxy. Only at the turn of the eighteenth century did Galician Ukrainians become Uniate. ${ }^{4}$ 
Thereafter virtually all Ukrainians in Galicia were Greek Catholics, and the Greek Catholics in Galicia Ukrainians.

Uniatism had been a dynamic religious movement in the late sixteenth and early seventeenth century, but by the time the Galicians accepted it much of the original fire had died down. The Galicians adopted Uniatism at the same time as, after half a century of strife, Poland was reconsolidating its rule in Western Ukraine, suppressing the Cossacks and reinstituting serfdom.

The Uniate church in Galicia suffered from neglect and discrimination for most of the eighteenth century. The vast majority of the clergy, uneducated and poor, lived little better than the peasantry. The elite of the clergy was composed of Basilian monks, from whom the hierarchy was appointed. There were some outstanding figures in the Uniate church, however, particularly the bishop of Lviv, Leo Sheptytsky (1749-79). Sheptytsky was influenced by the Polish enlightenment and used his good connections at the court to undertake some important ecclesiastical reforms. ${ }^{5}$

Galicia passed from Polish to Austrian rule in 1772 as a result of the first partition of Poland. The first decades of the new regime, particularly the reigns of the enlightened absolutists Maria Theresa (1740-80) and Joseph II (1780-90), were distinguished by far-reaching improvements in the affairs of the Greek Catholic church. Inferior in status under Polish rule, the church was now elevated to legal equality with the Roman Catholic Church. The eparchy of Lviv was raised to an archeparchy and Lviv also became the seat of the newly restored, after almost half a millennium's hiatus, metropolis of Halych (1808). The entire secular clergy of the Greek Catholic Church was given formal seminary training at institutions of higher learning in Vienna and Lviv. The income of the secular clergy was regularized and considerably increased by Emperor Joseph II. The Austrian authorities also confirmed Greek Catholic cathedral chapters (krylosy) in Lviv (1813) and Przemysl (1817) and resolved a decades-long conflict between the religious and the secular clergy in the latter's favor. Aside from reforms that directly concerned it, the Greek Catholic church benefitted indirectly from numerous reforms that improved the 
socioeconomic position of its faithful, who were overwhelmingly serfs. During the years from 1772 to 1815 , not surprisingly, the clergy and hierarchy of the Greek Catholic church developed a profound loyalty to the Habsburg dynasty.

In the following decades (1815-48) the most significant development was the initiation of the Ukrainian national awakening led by the Greek Catholic clergy. ${ }^{6} \mathrm{~A}$ consequence of the education of seminarians was the rapid formation of a stratum of intelligentsia for the submerged, largely enserfed Ukrainian population of Galicia. Influenced by contacts, particularly in Vienna, with the awakeners of other non-German nationalities in Austria, by the example, particularly in Lviv, of Polish romantic and insurrectionary nationalism and also by contacts with the emerging Ukrainian movement in the Russian empire, Greek Catholic seminarians, priests and even bishops began to engage in the "heritage-gathering ${ }^{17}$ work typical of the early stages of national movements. They codified their language, translated classics of world literature, composed poetry and literary prose, researched the history of Ukrainian Galicia and its church and recorded the folk songs, fables and customs of the people. The work was entirely cultural without overt political import. The national identity being defined was generally referred to by the awakeners as Galician-Ruthenian and considered a branch of the Little Russian or Ukrainian nationality. The national awakening absorbed most of the intellectual energy of the Greek Catholic clergy.

Within the church there were some differences of opinion about the national revival. Metropolitan Mykhail Levytsky (1816-58) adopted a conservative attitude, while the seminarians who formed the Ruthenian Triad (Markiian Shashkevych, Iakiv Holovatsky and Ivan Vahylevych) represented the most advanced wing of the national movement. At issue were such matters as language, with conservative churchmen favoring more emphasis on Old Church Slavonic and the radical youth a pure vernacular, and the degree to which liberal ideas circulating underground in the Vormärz (roughly the period of growing social and political pressure from 1835 to 1848) were to be integrated into the national revival. 
The revolution of 1848 brought substantial change to the Greek Catholic population of Galicia. Emancipation from serfdom set the stage for great cultural, social and political advancement over the following decades. The national movement also made the transition from a cultural to a political movement. During the revolution of $1848-9$, the Ukrainians of Galicia formed the Supreme Ruthenian Council, over which Bishop Hryhorii Iakhymovych ${ }^{8}$ presided and in whose leadership were many Greek Catholic priests. The Council demanded the division of the Austrian province of Galicia, which included ethnically Polish territory around Cracow in the West, into separate Polish and Ukrainian provinces. It also defended the interests of the newly emancipated peasantry. With regard to all-Austrian politics, the Council supported the emperor rather than those who rebelled against him. ${ }^{9}$

The political activism which the Greek Catholic clergy evinced in 1848-9 surfaced again in the 1860 s when a constitution and civil liberties were introduced in Austria. Priests were elected as deputies to the Galician diet and the all-Austrian parliament (Reichsrat). Although the secular intelligentsia began to assume the leadership of the national movement in the 1860 s, priests remained indispensable activists at the local, parish level, founding associations for adult education, economic cooperation and cultural activity as well as agitating for Ukrainian candidates during elections. ${ }^{10}$ For many priests, this national activism became an important component of pastoral work; for some, in fact, it even became the overriding concern. The Vatican was not unaware of the growth of nationalism among the Greek Catholic clergy and tried to stem it. The Vatican's opposition to nationalism had many sources, including the papal opposition to Italian nationalism, but the case of Greek Catholicism in Galicia had its own peculiarities."

The national movement in Galicia acquired profound confessional significance as the result of the division between those Ruthenians who identified with the Ukrainian movement in the Russian empire and those who looked instead to the tsarist Russian government. These latter, generally referred to in historical literature as Russophiles, began to argue that the Ruthenians of Galicia formed a branch of the 
Russian nationality. The Russophile tendency was dominant throughout the period from the defeat of the revolution in 1849 until 1882. This is not the place to discuss all the reasons for its emergence and consolidation, but most important was the feeling that Austria had betrayed its loyal Ruthenian population by giving control of Galicia to the Polish gentry.

The confessional implication of Russophilism was a gravitation toward the Russian Orthodox church. This must be understood in perspective, however, because more was involved than simply the influence of politics on religion. Greek Catholicism shared with Russian Orthodoxy descent from the church of Grand Prince Volodymyr (Vladimir); although Catholic, it was indisputably an Eastern Christian church. However, under Polish influence, particularly but not exclusively since the acceptance of the Union at the turn of the eighteenth century, the Galician church adopted certain customs and attitudes from Latin Catholicism. There were always those in the Galician church who opposed Latin influences as a break with religious tradition. With the awakening of national consciousness in the nineteenth century-a national consciousness that was anti-Polish-a movement for an easternizing purification of the Greek Catholic Church emerged, first in the 1830s and 1840s, but much more vigorously in the 1860s. The political Russophiles supported the religious easternizers and held up Russian Orthodoxy as an unsullied model, and the easternizers were often drawn nolens volens into the Russophile camp because of a certain community of interest. The Vatican opposed Latinization of the Greek Catholic Church, but it worried about the implications of a pro-Russian purification movement, especially since Bishop Siemashko had prefaced his defection from the Union with just such a purification campaign in the much more Latinized Belorussian church. Rome's hesitations and distrust of the Russophiles only played into their hands, as they more and more unmistakably insinuated that the Galician church could only be saved by a break from Rome. ${ }^{12}$

Tensions over these issues became explosive in the 1870s. For one thing, the deterioration of Austro-Russian relations over conflicts in the Balkans meant that the Austrian state was as distrustful of the Russophiles as the Vatican was. Also, in 
1875 , following a period of intense ritual purification, the last Uniate eparchy in the Russian empire, the Ukrainian eparchy of Chelm [Kholm], became Russian Orthodox. In the suppression of the Union a leading role was played by Galician Russophiles who had been recruited by the Russian government for pastoral and pedagogical work in the Chelm eparchy. The leading Russophile newspaper in Lviv, Slovo, was so sympathetic to the conversion to Orthodoxy that the Greek Catholic metropolitan forbade his faithful to read it. ${ }^{14}$

The tensions came to a head in 1882 when the Greek Catholic congregation of Hnylychky in Galicia requested permission to convert to the Orthodox faith. Viennese and Vatican authorities reacted in concert, swiftly and energetically. They forced Metropolitan losyf Sembratovych (1870-82) and his chief officials to resign, and a number of prominent Russophiles, including the priest Ivan Naumovych, were put on trial for high treason. ${ }^{15}$

The aftermath of the crisis of 1882 was marked by intense Vatican intervention in the Greek Catholic Church. During this period the priests promoted to higher rank were drawn from the leading lights of the journal Ruskii Sion. Founded in 1871, this journal consistently stressed loyalty to Catholicism, opposition to religious Russophilism and the subordination of national politics to religion. Men from this circle included Sylvester Sembratovych, who was made metropolitan in 1885 , and the eminent church historian Iulian Pelesh, who became the first bishop of Stanyslaviv in 1886. In 1882 the Vatican also arranged for the reform of the debilitated Basilian monastic order by the Jesuits. ${ }^{16}$ This was a reform of great significance for the Greek Catholic Church. Since its implementation, the Basilians have remained an influential factor in the church, known for their contributions in publishing and scholarship as well as for their absolute loyalty to Rome.

After the events of 1882 the Russophiles became both more marginalized and more extreme in their views. For some time, they had already been fighting against the growing power of the national populists (narodovtsi), as the adherents of the Ukrainian movement proper were called. The purge in the church and disgrace of the treason trial weakened them beyond recovery. 
Although the Ukrainian national movement proper gained by the new Vatican activism vis-à-vis the Greek Catholic Church, it nonetheless opposed it. Vatican influence was equated with Polish influence; and indeed, in the ecclesiastical interventions of the 1880s the interests of the Vatican and the local Polish gentry who controlled the Galician government did, in fact, coincide. Also, although the Ukrainian movement of the national populists was by no means anti-Catholic in the 1880 s, it did advocate the relative independence of its national church. Finally, Ukrainian leaders were generally hostile to Metropolitan Sylvester Sembratovych's efforts to promote conciliation between the Ukrainian movement and the Polish ruling class in Galicia; only for about two years (during the so-called New Era) did the metropolitan and the leaders of the national populists work hand in hand.

The end of the nineteenth century also witnessed the growth of anticlericalism in Ukrainian Galicia, particularly among the young intelligentsia and younger, more educated peasants. These strata formed the first formal Ukrainian political party in 1890 , the agrarian socialist and profoundly anticlerical Radical Party. ${ }^{17}$

The history of the Greek Catholic Church in the first half of the twentieth century is dominated by the figure of Metropolitan Andrei Sheptytsky (1901-44). ${ }^{18}$ When he was named bishop of Stanyslaviv in 1899 and not much later metropolitan of Halych, Ukrainian society suspected that he represented a continuation of the Roman, and consequently Polish, ascendancy in the Greek Catholic Church that had been evident since 1882 . This was because Sheptytsky was by birth a member of the Polonized nobility-in fact, a count-who changed from the Latin to the Greek rite in order to enter the newly reformed Basilian order. These suspicions, although persistent, proved to be completely misplaced. Sheptytsky showed himself to be a man of extraordinary vision who handled chronic problems in the Greek Catholic Church in a fresh and principled manner.

One such problem was the Church's relationship to the national movement. For much of the nineteenth century the clergy had been very active in promoting this movement, often allowing national concerns to overshadow religious ones, but in the two decades prior to Sheptytsky's accession relations between adherents of the 
national movement and the church had become strained. The new Vatican influence on the church injected a distrust of nationalism that had previously been almost absent in Greek Catholicism and the rise of anticlericalism among the younger intelligentsia further exacerbated tensions. Some clerics decided that the church should withdraw from and even oppose the national movement. The principal representative of this viewpoint was the bishop of Stanyslaviv, Hryhorii Khomyshyn (1904-46). Sheptytsky espoused a different and, for Galicia, new conception. In his view, the church had to remain independent of the national movement, ready to criticize and oppose it when it came into conflict with Christian principles, but equally ready to support it when it did not. Thus in 1908, for example, when a Ukrainian student assassinated the governor of Galicia and the national movement as a whole condoned the action, Sheptytsky strongly condemned the murder and was exposed to many insults as a result. But in numerous other instances, Sheptytsky used his exceptional influence-derived from his personality as much as from his office and aristocratic origin-to promote Ukrainian interests in Galicia. He established, for example, a Ukrainian National Museum in Lviv, to this day and through the most adverse times an outstanding center for the preservation of Ukrainian cultural artifacts. His successful mediation won agreements to increase the proportion of Ukrainian deputies in the Galician diet and to found a Ukrainian university in Lviv. Many scholars would agree that no individual in the first half of the twentieth century contributed as much to the Ukrainian cause in Galicia as Metropolitan Andrei Sheptytsky.

Another problem he approached with an original and positive vision was that of religious Russophilism. First, he was very tactful in dealing with the Russophiles among his clergy, which sometimes earned him the ire of zealous adherents of the Ukrainian national movement. Second, and much more important, he worked diligently to restore the Eastern traditions of his church, for example, by reviving eastern monasticism according to the Studite rule and, in the postwar period, implementing a thorough, purificatory liturgical reform. Unlike many other Easternizers, however, Sheptytsky was convinced that his restoration of the Byzantine 
spirit could be and had to be accomplished within the parameters of what he considered the universal church-i.e., the Catholic Church. He was also extremely distrustful of the contemporary Russian Orthodox Church, which was, of course, closely associated with the tsarist regime. Not only was Sheptytsky an Easternizer free from political Russophilism and gravitation to the Russian synodal church; he actually sought to expand the Union into Russian and other Orthodox territory, travelling incognito into Russia before World War I to make contact with sympathizers.

Soon after the world war broke out, Galicia was occupied by Russian forces. The Russian occupation authorities persecuted the Greek Catholic Church, arresting Sheptytsky and undertaking measures for the forcible conversion of the Galician Uniates to Orthodoxy. In the end, however, the unpopular Russian policies only raised the prestige of Sheptytsky and the Greek Catholic Church among the Galician Ukrainian population. After the February Revolution in Russia, Sheptytsky was released. When he returned to Galicia he was welcomed as a martyr for church and nation. ${ }^{19}$

In the fall of 1918 Austria-Hungary collapsed. The Ukrainians of Galicia established the West Ukrainian National Republic, but their right to Galicia was contested by the revived Polish Republic. A Ukrainian-Polish war over Galicia lasted until the summer of 1919, when the Ukrainian forces were beaten back and Poland occupied all of Galicia. During the conflict, the Greek Catholic Church supported the Ukrainian national forces.

In the interwar era and into the years of World War II, the Greek Catholic Church remained a prominent factor in Ukrainian national affairs. This was partly due to the continuing prestige and influence of Metropolitan Sheptytsky (Bishops Khomyshyn of Stanyslaviv and Iosafat Kotsylovsky [1917-46] of Przemyśl, on the other hand, were rather unpopular, especially for introducing a celibate parish clergy in their eparchies). Another factor, however, was the deterioration of the position of the Ukrainian secular intelligentsia. In the last decades of Austrian rule the Ukrainian secular intelligentsia had assumed the leading position in Ukrainian 
national life. They still remained the leaders in interwar, Polish-ruled Galicia, but their effectiveness was greatly reduced. The new Poland was less democratic than the old Austria, and the elected leaders of national minorities were essentially powerless. The Ukrainian educational institutions that Poland inherited from Austria were largely dismantled, meaning that Ukrainian educators and scholars had difficulty finding work commensurate to their interests and talent. ${ }^{20}$ Discrimination against Ukrainians and other non-Poles for the most part closed opportunities for them to make careers in the civil service. The weakening of the secular intelligentsia under the new regime raised the relative importance of the clergy and the church in national life. The Ukrainian priest was naturally a more crucial factor in a village without a Ukrainian teacher, and in the absence of other Ukrainian institutions of higher learning the Greek Catholic Theological Academy, founded by Sheptytsky in Lviv in 1928 , became the leading center of advanced education and scholarship for Galician Ukrainians as a whole. ${ }^{21}$ Similarly, for a nation without a state an imposing figure like Sheptytsky could function as a surrogate president. The Greek Catholic Church's leadership-by-default accounts for the unusual prestige of this church as an institution in interwar Galician Ukrainian society.

In the interwar years and especially during the years of the Nazi occupation of Galicia (1941-4), the Church faced a much more acute version of a problem it had already confronted in the Austrian period: what Sheptytsky called "politics without God." Frustrated in their aspirations for independent statehood, a minority in an authoritarian, nationally oppressive state, Ukrainian nationalists resorted to political terrorism in the 1920 s and 1930 s to further their aims, accomplishing several spectacular assassinations. The Church, and in particular Sheptytsky, condemned these actions as murder and reiterated the view that political motivation cannot excuse grievous sin. During World War II Sheptytsky condemned the bloody factional struggle between the Bandera and Melnyk wings of the Organization of Ukrainian Nationalists as well as the murder of Jews by the Nazis and Nazi collaborators. In this context, in November 1942 he issued a pastoral letter entitled "Thou Shalt Not Kill," which once again made explicit the church's teaching that political murder is 
a sin and which in fact made murder a reserved sin that only the bishop could absolve. Judging by the frequency with which Sheptytsky had to speak out against political murder and by the historical record of politically motivated bloodshed in Galicia during the interwar years-in, particular, during World War II-it seems that the Church's prestige as a national institution did not readily translate into effectiveness as a moral force.

As a result of the Hitler-Stalin pact and division of the Polish state, Galicia came under Soviet rule in 1939. Although the Germans expelled the Soviets in 1941, the Soviets reconquered the region in 1944 and it remained under Soviet rule until the proclamation of Ukrainian independence in 1991. The communist authorities began to persecute the Greek Catholic Church as soon as they acquired Galicia in 1939, but the persecution became relentless after Sheptytsky, with whose popularity the authorities reckoned, died in November 1944. All the bishops of the church were arrested and exiled, as were great numbers of priests. In 1946 the secret police orchestrated the (uncanonical) Synod of Lviv, which formally united the Greek Catholic Church of Galicia with the Russian Orthodox Church. There was probably a complex of motives behind the Stalinists' elimination of the Greek Catholic Church, but a prominent motive must certainly have been to put an end to the Church's role as a Ukrainian national institution. The Church continued an underground existence in Galicia, particularly starting in the 1950s, when many of its priests were amnestied. $^{22}$ As a catacomb church it enjoyed great prestige among Ukrainian dissidents in the 1960s, 1970s and 1980s.

With the introduction of some democratic reforms in the Soviet Union in the late 1980s, the Greek Catholic Church reemerged as a public force; at the end of 1989 it began to function legally, primarily in Galicia but also elsewhere in Ukraine. The church today views itself and is viewed by many others as a national church. ${ }^{23}$ However, it has been challenged, even and indeed especially in Galicia, by the Ukrainian Autocephalous Orthodox Church, which also considers itself a national church. The adherents of the autocephalous Orthodox Church argue that Uniatism is a local, West Ukrainian phenomenon unacceptable to the majority of Ukrainians 
living in Central and Eastern Ukraine, who are by tradition of the Orthodox faith. The emergence of two national churches on the same territory has engendered a bitter religious conflict in which questions of national political strategy are primarily at issue.

In modern Ukrainian history the Greek Catholic Church stands out for its contribution to the national awakening and organized national movement. Its role as a national church, albeit on a local, Galician level, is particularly apparent when contrasted to that of the Russian Orthodox Church, to which most Ukrainians, the population of Central and Eastern Ukraine, adhered. In the nineteenth and twentieth centuries, with few exceptions, the clergy and even more so the hierarchy of the Russian Orthodox Church in Ukraine remained apart from and often hostile to the Ukrainian national movement. The Russian Orthodox Church functioned, in fact, as an instrument of Russification, both in tsarist times and in the Soviet period.

The contrast suggests some interesting questions: to what extent was the difference in attitudes toward the national movement a reflection of some fundamental differences between Catholicism/Uniatism and Orthodoxy? Was there something about Uniatism that made it a more suitable national church, particularly for stateless, submerged nations like the Ukrainians of Galicia or Romanians of Transylvania?

A rather strong case can be made against the view that Uniatism was inherently a more suitable vehicle for nation-building than Orthodoxy. One does not have to look very far from Ukrainian Galicia to find either anational Uniatism or national Orthodoxy. On the other side of the mountains from Galicia, in the Hungarian-ruled region of Transcarpathia, the Greek Catholic clergy was unsympathetic to the Ukrainian or Rusyn national movement in the late nineteenth and early twentieth centuries. Greek Catholic priests there promoted Magyarization and Hungarian patriotism rather than the development of an autochthonous Ukrainian or Rusyn culture and the pursuit of political self-determination for the local population. ${ }^{24}$ There was also in Ukraine an example of a nationally conscious Orthodoxy, ${ }^{25}$ the above-mentioned Ukrainian Autocephalous Orthodox Church. This church emerged during and immediately after the failed revolution to establish an 
independent Ukrainian state in 1917-20. It was really a deliberate creation of the national movement, which reacted to the hostility of the traditional Russian Orthodox Church by establishing a new ecclesiastical organization that would be both Orthodox Christian and pro-Ukrainian at the same time. The examples of Transcarpathia and Ukrainian autocephaly have more complexities than can be suggested here, but they do indicate that there is no simple congruence between Uniatism and support for national aspirations, on the one hand, and Orthodoxy and national indifference or hostility, on the other.

A major problem in trying to ascertain to what extent religious differences account for differing attitudes toward national movements is that other critical factors also come into play. In particular, the role and nature of the state deserve careful consideration. The Greek Catholic Church functioned in relatively democratic Austria, where the Ukrainian movement was allowed to develop with only minor hindrances after 1867. Priests could establish and take part in voluntary associations, write for Ukrainian newspapers and run for parliament, generally with minimal negative repercussions. The Orthodox church faced completely different conditions in autocratic Russia, where the Ukrainian language was banned from print and schools and where participation in the Ukrainian movement could bring severe reprisal from the state. It is important to note that the state had a particularly powerful influence on Russian Orthodoxy, one that could easily determine its relation to the Ukrainian national movement. During the imperial period, the Russian Orthodox Church was virtually a branch of the government, and in the Soviet period it was reduced to the status of a marionette.

The case of the anational Uniate church in Transcarpathia can also be explained in terms of its relationship to the state. The Hungarian part of the Habsburg empire after 1867 was relatively undemocratic, and the government systematically pressured Slavs and Romanians to assimilate to the Magyar national identity. Similarly, the case of the national, Autocephalous Orthodox Church shows the influence of the state: Ukrainian autocephaly only emerged after the collapse of 
tsarism in the unsettled revolutionary and post-revolutionary period, and it was brutally eradicated in the 1930 s by a totalitarian and anti-Ukrainian Soviet regime.

The Austrian state influenced Uniatism in Galicia (and to some extent in Transylvania as well) by infusing it with a more modern, secular, service-oriented spirit than existed in Orthodoxy. The Greek Catholic Church owed its very name and much of its institutional structure and intellectual formation to the Austrian enlightened absolutists. It was thus inevitable that this church would assimilate the outlook of the Austrian enlightenment, including many Josephinist principles. Such a "modernizing" underlayer was absent in Russian Orthodoxy, and this difference may well account for part of the divergence in the two churches' receptivity to the Ukrainian national movement.

Another factor must also be taken into consideration. Eastern-rite Christianity, whether Uniate or Orthodox, was an effective differentiating factor in relation to the Poles (and most Magyars) who were of the Latin rite, but it was an integrating factor in relation to the Russians and Romanians who shared the Eastern rite. In Bukovina, in spite of the linguistic distance between the local Ukrainian and Romanian Orthodox populations, there was considerable assimilation of Ukrainians to the Romanian nationality (and vice-versa) via the shared church and rite. Thus the divergence between Greek Catholicism and Russian Orthodoxy with regard to the national question can be understood as a natural result of the circumstance that one differentiated Ukrainians from the rival, politically and socially dominant nationality, while the other integrated them into it.

In light of what has been said above, it may seem that the differences between Uniatism and Orthodoxy as such had nothing to do with the dissimilar national stances assumed by the Greek Catholic Church in Galicia and the Russian Orthodox Church in Central and Eastern Ukraine. So many causes and subtle determinations enter into the picture, it is difficult to pronounce on the question with any certainty. However, two further factors that must be taken into account for a complete explanation do relate to the essential qualities of Orthodoxy and Uniatism. 
First, Uniatism, by virtue of its union with Rome, has an important dimension of local transcendence that is lacking in Orthodoxy. The Roman administration of the Catholic church-i.e., the pope and his colleges and secretariats-has certain rights of intervention into the affairs of the particular Uniate churches, and the policies it pursues in these interventions are often dictated by the perceived interests of the universal church rather than by local interests. This Roman dimension gave the Uniate churches some degree of freedom from the immediate political (or political-ecclesiastical) authorities. Rome functioned as the ecclesiastical equivalent of Vienna, which at times intervened to mitigate Magyar domination of the Romanians in Transylvania and Polish domination of the Ukrainians in Galicia. The existence of an interested and authoritative third party outside the arena of national conflict tended to work to the advantage of the weaker, submerged nationalities like the Ukrainians and Transylvanian Romanians. In Orthodoxy not only was this dimension absent, placing the weaker, stateless nationalities in a more difficult position, but the traditional close association between Orthodox churches and existing state structures also worked in favor of the dominant nationality. Thus it would seem that Uniatism had greater potential than Orthodoxy to intervene positively in the national development of the "nonhistoric" peoples of East Central Europe.

Second, Uniatism incorporated many spiritual values and institutional arrangements of the Catholic counter-reformation, which had in fact contributed to its emergence. This particular formative substratum was absent in Orthodoxy, which knew neither reformation nor counter-reformation. The participation of Uniatism in the major readjustment of Christianity to the more secularized society of early modern Europe may also have had an effect on the eventual receptivity of Uniatism to national movements. In any case, this question requires more elaboration and investigation. 


\section{Notes}

1. The portion of this essay dealing with the period from 1772 to 1914 is based on my article, "The Greek Catholic Church in Nineteenth-Century Galicia," in Church, Nation and State in Russia and Ukraine, ed. Geoffrey A. Hosking (London: Macmillan in association with the School of Slavonic and East European Studies, University of London, 1991), pp. 5264. Material drawn from the earlier article is used with permission of the publisher.

2. The best general histories of the Greek Catholic Church in Galicia are: Mykhail Harasevych [Michael Harasiewicz], Annales Ecclesiae Ruthenae (Lviv, 1862); and Iulian Pelesh [Julian Pelesz], Geschichte der Union der ruthenischen Kirche mit Rom von den aeltesten Zeiten bis auf die Gegenwart, vol. 2 (Würzburg, Vienna, 1881); Anton Korczok, Die griechisch-katholische Kirche in Galizien (Leipzig and Berlin, 1921). A detailed bibliography may be found in Isydor I. Patrylo, Dzherela i bibliohrafiia istorii ukrains'koi tserkvy, Zapysky ChSVV, II, Sektsiia I: Pratsi, 33 (Rome, 1975); additions by the same author and under the same title have appeared in Analecta OSBM, 10 (16) (1979), pp. 406-87, and 12 (18) (1985), pp. 419-525.

3. Ivan L. Rudnytsky, "The Ukrainians in Galicia under Austrian Rule," in Essays in Modern Ukrainian History (Edmonton: Canadian Institute of Ukrainian Studies, 1987), pp. 315-52.

4. Przemyśl eparchy accepted the Union in 1692, Lviv eparchy in 1700 and the Stavropegial Brotherhood in Lviv in 1708.

5. See John-Paul Himka, "The Conflict between the Secular and the Religious Clergy in Eighteenth-Century Western Ukraine," Harvard Ukrainian Studies 15, no. 1-2 (June 1991): $35-47$. 
6. See Jan Kozik, The Ukrainian National Movement in Galicia: 1815-1849, ed. Lawrence D. Orton (Edmonton, 1986).

7. Paul R. Magocsi, "The Ukrainian National Revival: A New Analytical Framework," Canadian Review of Studies in Nationalism 16, 1-2 (1989): 50.

8. There is a good scholarly biography of this bishop and later metropolitan (1860-3): Luigi Glinka, Gregorio Jachymovyč-Metropolita di Halyč ed il suo tempo (1840-1865), 2nd ed., Analecta OSBM, Series II, Sectio I: Opera, 30 (Rome, 1974).

9. Martha Bohachevsky-Chomiak, The Spring of a Nation: The Ukrainians in Eastern Galicia in 1848 (Philadelphia, 1967).

10. See John-Paul Himka, Galician Villagers and the Ukrainian National Movement in the Nineteenth Century (Edmonton, 1988), especially pp. 105-42.

11. Very revealing is a survey of the ecclesiastical affairs of the Slavs and Romanians in the Habsburg empire prepared by the Viennese Nuncio Mariano Falcinelli Antoniacci in March, 1864. The document is published in Gabriel Adriányi, Ungarn und das I. Vaticanum (Cologne: 1975), pp. 396-407.

12. For example: "The Union was always and remains to the present time the most insidious and dangerous invention in all respects-religious, national and political. The Union was contrived by the Jesuits as a means to catholicize the Orthodox and polonize the Russians...." "Polytycheskoie znacheniie relyhioznoi unii," Slovo, 15, no. 6 (16 [28] January), p. 1.

13. Luigi Glinka, Diocesi ucraino-cattolica di Cholm (Liquidazione ed incorporazione alla Chiesa russo-ortodossa) (Sec. XIX), Analecta OSBM, Series II, Sectio I: Opera, 34 (Rome, 1975).

14. I. K., "Odna duzhe vazhna sprava...," Ruskii Sion, 5 (1875), p. 301. 
15. Excellent archival documentation on these issues can be found in Archivio Segreto Vaticano, Archivio della Nunziatura di Vienna, vols. 570 and 587, and in Vienna's Haus-, Hof- und Staatsarchiv, Administrative Registratur, F. 28, K. 11.

16. In Documenta Pontificum Romanorum historiam Ucrainae illustrantia (1075-1953), vol. 2: 1770-1953, ed. Athanasius G. Welykyj, Analecta OSBM, Series II, Sectio III: Documenta romana Ecclesiae Unitae in terris Ucrainae et Belarussiae (Rome: PP. Baasiliani, 1954), pp. 452-9.

17. On radicalism, see John-Paul Himka, Socialism in Galicia: The Emergence of Polish Social Democracy and Ukrainian Radicalism (1860-1890) (Cambridge, 1983).

18. Morality and Reality: The Life and Times of Andrei Sheptyts 'kyi, ed. Paul R. Magocsi (Edmonton, 1989). Cyrille Korolevskij, Metropolite André Szeptyckyj 1865-1944, Opera Theologicae Societatis Scientificae Ucrainorum, 16-17 (Rome, 1964). An as yet unpublished English language translation of this work has been prepared by Rev. Brian [Serge] Keleher. Gregor Prokoptschuk, Metropolit Andreas Graf Scheptyckyj: Leben und Wirken des grossen Förderers der Kirchenunion, 2nd ed. (Munich, 1967). Of particular merit is: Sophia Senyk, "Le métropolite André Šeptyc'kyj: Dimension spirituelle de sa vie et de son oeuvre, "Irénikon 64, no. 1 (1991): 57-71.

19. Tsars'kyi viazen' 1914-1917 (Lviv, 1918).

20. For example, the outstanding historian Ivan Krypiakevych had to earn his living teaching secondary school and writing popular and semi-popular works.

21. Krypiakevych taught there from 1934 to 1939.

22. Bohdan R. Bociurkiw, "The Uniate Church in the Soviet Ukraine: A Case Study in Soviet Church Policy, " Canadian Slavonic Papers 7 (1965): 89-113. 
23. Vasyl' Ivanyshyn, Ukrains'ka tserkva i protses natsional'noho vidrodzhennia, 2nd ed. (Drohobych, 1990).

24. Atanasii V. Pekar, Narysy istorii tserkvy Zakarpattia, vol. 1: Ierarkhichne oformlennia, Analecta OSBM, Series II, Sectio I: Opera, 22 (Rome: PP. Basiliani, 1967), pp. 95-112.

25. Of course, Orthodoxy played a role in the development of Russian, Serbian, Greek and Bulgarian nationalism-but a different role in each case. 


\section{The Uniate Church in Belorussia: \\ A Case of Nation-Building?}

\section{James T. Flynn}

The role of Uniate Churches in the development of some modern nationalisms in Eastern Europe has attracted the attention of scholars who seek to explain the special characteristics of either nationalism in Eastern Europe or of Uniatism. ${ }^{1}$ To be sure, religion, or churches at any rate, have played a role in the development of nationalism in Western Europe as well. In the West, however, the national church was usually the church of the majority, such as the Church of England or the Catholic Church in France, the "Gallican" church, which enabled the community to use the traditional society's signs of sacredness, of enduring values, in support of the new ideology of modern nationalism. These churches played a subordinate role, for they cooperated with, but did not lead, the development of modern nationalisms. Moreover, churches of low status minorities, such as the Methodists in eighteenth century England, or even of elite minorities, such as the Anglicans in Ireland in the eighteenth century, did not succeed in nourishing the sort of separatism that became nationalism in the nineteenth century. Thus, the contrast with developments in Eastern Europe was very sharp. In Eastern Europe, while the churches of the majorities, such as the Orthodox Church in Russia or the Roman Catholic in the Habsburg domains, cooperated with developing nationalisms, the churches of low status minorities became leading institutions for rising nationalisms.

Nationalism was a secular ideology that soon shed clerical leaders. In the transition from traditional societies to modern, one aspect of which has been the development of nationalism, churches have tended to play a transitional, i.e., 
temporary, role in which the first generation of leaders, recruited from the traditional elites of clergy and nobility, are replaced by secular professional elites. The experience of churches that not only nourished incipient nationalism in the past but continued to provide a key institution for the development and transmission of a community's sense of itself as a nation even in the twentieth century may, therefore, help explain the special characteristics of Eastern Europe, if only because the experience seems so different from that which transpired in the West.

The cases of two Uniate Churches in Eastern Europe, the Ukrainian Catholic Church and the Romanian Uniate Church, have been well studied. ${ }^{2}$ The Uniate Church of Belorussia has not been well studied from this point of view, because the Church was destroyed in early nineteenth century, a victim of the Russian Empire's first effort to replace its eighteenth-century cosmopolitanism, the imperialism of the enlightened, with its own version of Romantic nationalism, Official Nationality. The government of Tsar Nicholas I (1825-55) the Uniates into the Russian Orthodox Church, having arranged the 1839 Synod of Polock to make the Uniates an offer they could not refuse. This paper compares the experience of the Uniate Church in Belorussia with the Ukrainian and Romanian churches in hope of locating a factor or factors present in those churches but missing in the Belorussian in order to explain, however tentatively, the different outcomes for churches that were founded for similar reasons in similar circumstances.

The origin of the Uniate Churches in all three cases was the desire of some Orthodox bishops for the advantages of connection with a powerful western government. All were founded in similar socioeconomic and even political settings, agrarian societies of poor peasants ruled by nobles whose authority was not effectively checked by centralized monarchy, despite the hopes or expectations of the bishops who made the unions that the monarchies could and would provide them with security.

At the outset, it does not seem likely that a Uniate Church in the Russian Empire could function as a national church of the Belorussians, if only because its very existence was repeatedly in question. ${ }^{3}$ The Union of Brest was made in 1596 
by some Orthodox bishops in Ruthenia, roughly the area of Belorussia and Ukraine then part of the Polish-Lithuanian Commonwealth. This union founded the Ruthenian Catholic Church, and provided guarantees of the rights of the bishops to their dioceses, the bishops' acknowledgement of the religious authority of the pope at Rome and the secular authority of the Polish king, and included a typical statement of the essentials of the Christian faith, complete with filoque clause. Such matters were of slight concern to the majority in the parishes, the peasant faithful. For them the union's promise was the continuation of their cherished religious practices, their Byzantine-rite liturgy sung and prayed in Slavonic and in accordance with Orthodox custom, ikons and all, safe from the imposition of the western, in this case Polish, customs and practices that usually accompanied inclusion in the fold of western Christendom.

The Union of Brest thus promised to the elite, including the bishops and scholars of the monastic communities, not only continuation in office but the rewards of close connection with the rich intellectual and cultural achievements of the Christian West. At the same time the Union preserved the eastern liturgy and promised safeguards against the instrusion of western religious influence for the overwhelming majority of the faithful, the priests and peasants in the villages. This double promise, of connection with the western community but protection from submersion in it, was the source of the union's strength and its weakness, as well as the tension that springs from deep-rooted ambiguity.

To make good its promise, and thus provide an institution capable of nourishing the rise of a modern sense of national identity among its faithful, the church in Belorussia needed first to survive. At many junctures in its history, this seemed unlikely. In the brutal, many-sided civil war that engulfed Eastern Europe in the seventeenth century, an organization centered in the south and east of the Polish-Lithuanian Commonwealth and representing a success for the West against Muscovy was in a perilous place indeed, and suffered much. The armed protectorate over Poland established by Peter the Great, whose interest in the West did not lessen 
a hatred of Uniates that matched in ferocity the most tradition-minded among the Orthodox, also threatened the union.

The partitions of Poland in late eighteenth century cut the Ruthenian Catholic Church in two. Half the Church survived in the Habsburg portion of the partition, to become in time the Greek Catholic Church in Galicia, while the other, the union in Belorussia under Catherine the Great (1763-96), was subjected to a program of confiscations and mergers into the Russian Orthodox Church that promised to extinguish the Uniate Church in the Russian Empire in the not-very-long run. At the end of Catherine's reign, the Church had been reduced to perhaps a million and a half faithful, from a mid-century high of perhaps four million, in parishes located in the provinces of the Polish Commonwealth that were taken by Russia in the partitions. The active bishops numbered only one, for the others lived under virtual house arrest in St. Petersburg, unable to practice their offices. While Catherine supported the Jesuits, the Roman Catholic teaching order, she systematically reduced the number of schools and monasteries of the Uniate's teaching order, the Basilians.

Nonetheless, the Church still survived and in the first three decades of the nineteenth century experienced a remarkable revival. ${ }^{4}$ When Alexander I (1801-23) began to reform the state's relationship to the churches by renewing, or founding new, bodies to supervise each religious community, he decided that the Uniates in the empire would be represented in the Roman Catholic College chaired by the bishop who served as metropolitan of the Roman Catholic Church in the Russian Empire. But Alexander soon became convinced that the Uniates should have their own separate office. Thus, the Uniate bishops so recently under house arrest were able to reorganize the Church into dioceses and to work at renewal of the dioceses. They made good use of the opportunities, not only reorganizing the diocesan structure, but persuading many parishes and clergy lost to Orthodoxy under Catherine to return to the union. In 1806, the same year that the Habsburg emperor appointed a metropolitan bishop to govern the Uniate Church in Galicia, Tsar Alexander appointed the bishop of the Uniate diocese of Polock "Metropolitan of the Uniate Church in Russia." 
Rome rejoiced at the resurrection of the Greek Catholics by the Russian government, but thought it should be consulted on the choice of bishops. Both the renewed Uniate hierarchy in Russia and the papacy, which in fact had no choice but to accept the tsar's decisions, welcomed the opportunity extended by the government of Alexander I. Thus, at the begining of the nineteenth century, before the culmination in mid-century of the "springtime of nations" in Eastern Europe, there had come into existence a separate, autonomous Uniate Church in Belorussia that took care to maintain its connections with Rome while assuring the Russian Empire that its faithful were loyal to the tsar.

In order to make its survival as an institution into an instrument for the stimulation of a modern national consciousness among the people of Belorussia, the Church would need to develop a modern standard language, taught in schools and generally accepted as a national language, replacing the local dialects as the "native language" of the people. The Church too would need to stimulate a sense of a homeland, not the universal Kingdom of God but a clearly defined space larger than the peasants' traditional village world and possessing a history. That history, the history of the people who share a common language and common homeland, would need to be special, that is, Romantic in impulse: the history of a particular, unique people whose origins and development mark and define progress for the people. These three essentials of modern nationalism-common language, homeland, and history-needed to be held together by a code of values and conduct, a religion, that not only explains and defines life itself but sanctifies the way of life of the particular people in question. Naturally, if language is essential, so is literacy; while history and religion lead directly to high culture, the diocesan structure of the Church located it and its faithful not only in a world of peasant villages but in a definite place and time. $^{6}$

All this could be said in some measure about almost any Christian Church since the Reformation, to be sure, but it was particularly the case for the Uniate Churches in Eastern Europe. The Church in Romanian Transylvania in the course of the eighteenth century developed an educational system to train its clergy, wishing 
to profit from the example and precept of the West. The seminaries, which were set up with western help, fostered the development of a clergy whose educational level was much higher than the traditional clergy, parish priests trained at home by their fathers whose places they were to take. This new clergy took a leading role in defining modern Romanian nationalism. They were the first-generation elite who developed and propagated a modern Romanian language, who developed a written history and literature, and who in fairly short order formulated demands for the recognition of the nation whose development they represented.

It was important, of course, that the result was not simply a defense of traditional peasant mores, but a new, relatively high culture that cherished and nourished some old values. This new culture was the channel through which the Enlightment entered the villages, not only mobilizing peasant energies in defense of the national way of life, but introducing the modern notions of technological change, social mobility, and economic progress, all aspects of modernity that carried with them the promise of progressive change. Coming from another source, from a centralized monarchy fostering its own "revolution from above" for example, such aspects of modernity might have provoked a reaction, a defense of tradition as the villages' own way. Coming from the people's own church, such aspects of modernity became part of a package of change that nourished, not threatened, the sense of national community.

There were, to be sure, problems, among them the problem of "Latinization." Among the western influences transmitted to the villages by clergy educated in seminaries that brought them into contact with western culture was a gradual, but clear enough, shift in the Byzantine-rite liturgy. It came increasingly to deviate from custom, if not Orthodoxy, and thus to become less eastern. A Uniate Church perceived as becoming a second-rate version of the Latin church was not likely to hold the trust of the people who looked to the church to maintain in purity the sacred signs of their faithfulness. Moreover, a clergy that became progressively more elite and westernized became harder for the community to distinguish from other elites-the Magyar nobility, or German bureaucrats, or businessmen. 
However, since the Roman Catholic bishops, Magyar or German, with at least the tolerance of the Vatican, often did regard the Uniates as second-rate Catholics, the danger of a split between modernizing Romanian Uniate clergy and tradition-oriented villages was minimized. Instead, the threat of Magyarization was a good part of the social cement that bound together the clergy and the peasants in the development of a specifically Romanian nationalism. ${ }^{7}$

In any event, it seems clear enough that the Romanian Uniate Church in Transylvania, until 1948, when it was forced into a merger with the Orthodox Church by another "revolution from above," was indeed a key institution in nourishing national feeling. Modernity produces change, of course, and change produced the rise of a new secular nationalist elite, who since they challenged the clergy for leadership of the national community, almost by necessity became anti-clerical. Nonetheless, the rise of an anti-clerical national leadership itself testifies to the importance of the clergy in the nationalist development.

A similar point could be made about the Uniate Church in Galicia, for the Greek Catholic clergy were challenged successfully by a rising secular elite for leadership of the national movement. Nonetheless, until it too in 1946 was forced into merger with the Russian Orthodox Church by another "revolution from above," the Greek Catholic Church in Galicia remained an important institution in Ukrainian nationalism. ${ }^{8}$ In the first half of the nineteenth century, the Greek Catholic Church nourished the growth of a sense of separateness among the Ruthenian/Ukrainian peasantry and provided its leadership. Naturally, it did not solve all the problems on the way to becoming fully developed, independent nation state, or gain an invitation to Galicia to join the League of Nations when the multinational empires of Eastern Europe were destroyed in World War I. On the other hand, the days when Ukrainians in Galicia might think of themselves as some sort of Poles, or some sort of Russians, were long over.

The Church had its center at the main seminary in Lviv (Lwow, Lemberg). Although it had a great church, St. Barbara's, in Vienna, its homeland was known to be marked by the boundaries of its dioceses. Polish remained the main language 
of administration and dominated in the schools, both secondary and higher, as well as in the cultural life of Galicia as a whole. Yet few doubted that the leadership of figures such as Bishop Snihurskyi, who established a teachers' college and fostered primary schools, helped create a literate public that by mid-century read the press that ultimately defined standard Ukrainian as a national language rather than a collage of local dialects. Moreover, the sense of a common history, of progress as a nation that was not simply the village nor part of some greater "Jagiellonia," let alone Russia, had gone far beyond the merely negative definition that Greek Catholics were neither Poles nor Russians.

Could the Uniate Church in Belorussia have made similar steps in nation-building had it not been suppressed by the government of Nicholas I in 1839 ? Belorussia, like much of Eastern Europe, lacks obvious, clearly defined frontiers. Under Alexander I, indeed, the boundaries of the dioceses, as well as their number, shifted with the fortunes of Russia's great struggle with Napoleon. Nonetheless, by 1815 , the diocesan structure of the Uniate Church defined the boundaries of an area recognized as Belorussia, which was used by other agencies, including the Ministry of Education. Although the metropolitan's office and the governing "college" of the Church were located in St. Petersburg, they avoided the invitation to build their cathedral there, but instead maintained the cathedral at Polock as the liturgical center of the Church. Joseph Semashko, who later led the Church into union with the Orthodox state church in 1839, was consecrated bishop in the Roman Catholic Church of St. Catherine in St. Petersburg. But most consecrations and ordinations were celebrated in Polock. Thus, while the metropolitan apparently was reluctant to discuss the matter too forcefully with Tsar Nicholas I, the steps taken by the hierarchy of the Church had the effect, and doubtless the intent, of identifying the church with a definite homeland that was not Russia.

The language of instruction in the main seminary at Vilna was Polish. The state sponsored university at Vilna included a "Main Seminary" whose mission was the education of clergy for both Roman and Uniate Catholic Churches. The spirit of the Enlightenment, or of Josephinism, animated the university. It successfully 
trained leaders for both churches who appreciated the Enlightenment's modern secular learning and were able to put it to the service of the churches. ${ }^{9}$ Both groups in the seminary attended the other's liturgies and came to appreciate the riches of the other's traditions. Although the university operated in Polish, it trained civil servants for the Russian imperial services, and priests for the villages of Belorussia. The diocesan seminaries were a good deal weaker, of course. Indeed, only two survived more than briefly. The seminary at Polock was able to send its students to the nearby Jesuit college to complete their preparation for university admission at Vilna. Unlike at Vilna, the Polish students at Polock resented the Uniates, for the most part sons of village priests who had prepared for the seminary in Basilian or, more rarely, public schools. The resentment came out in name-calling and occasional pushing and shoving. The Uniate clergy, then, although their schooling in Polish and at the university brought them into close and supportive contact with Polish clergy, were not converted to Polonism, but had their sense of separateness strengthened by both experiences.

The Church, moreover, consistently supported a program of "purification" of its liturgy and practices, successfully keeping its practice and worship consistent with the heritage of Eastern Christianity. Bishop Lisowski, who took a leading part in the organization of the Uniate "college" for administration in the early days of Alexander's reign-and perhaps for that reason was chosen Metropolitan in 1806-also led in stressing the importance of the Eastern rite liturgy in the life of the Church. Some of the Church's leaders, such as Michael Bobrowski, the son of a village priest and a professor of scripture at Vilna, became prolific scholars who wrote in Polish but also made significant studies in the development of Church Slavonic and taught practical courses in preaching in the local languages. By 1839 , a Church-sponsored press, publishing in Belorussian, had not appeared. On the other hand, it seems clear enough that there existed Uniate clergy who were both able and willing to initiate such a press.

Whether a church whose presence and practice naturally pointed to recognition of a homeland and the development of a standard, literate, version of the 
local language in Belorussia would also define for itself a history on national terms seems doubtful. When the Kharkov-trained historian Nikolai Kostomarov, who wholeheartedly approved of the government's suppression of the Uniates, in 1842 attempted to publish a history of the Uniates that would show that the government was right to abolish an organization likely to obstruct Russification, his work was suppressed. Nicholas I's minister of education, S. S. Uvarov, found it not enough that Kostomarov praised the suppression of the Uniates. Uvarov wanted no discussion of the Uniates at all, for what one writer described as "the peril of Uniatism" might appeal to readers as its hopeful promise. ${ }^{10}$ The only account available was the textbook history by Uvarov's protege at St. Petersburg University, Th. N. Ustrialov, who argued that Belorussia was part of historic Russia and that was all there was to be said. Clearly, the development of a progressive history of Belorussians would require a new set of circumstances.

The new set of circumstances Belorussians required was a translation into the Habsburg Empire. Father Bobrowski, who spent five years in study abroad, much of it in Vienna and Lwow, said as much in a report he sent to his colleagues at the Vilna Seminary in 1818, full of praise for the Habsburg administration and the health of the Uniate Church in Galicia. In 1828, when the Russian government forbade the continued enrollment of Uniates in the seminary at Vilna, Bobrowski's academic career in the university ended. Nonetheless, in 1834 he wrote a comforting analysis of the situation, consoling a former colleague at Vilna who was worried that the steps the Russian government was taking in regard to their church threatened its future. Bobrowski thought that the steps the government had ordered, including requiring separate seminaries for Uniates, using liturgical books printed in Moscow rather than Rome, and requiring the Basilian monks to share their property with the white, parish clergy, had all been taken in the Habsburg Empire to the profit, not peril, of the Uniate Church. Moreover, he said, "the continuation or fall of the Union...depends on the will of God, not on reforms." Finally, since Nicholas, "our emperor, upholds toleration for all faiths in the empire, none is forced to change religion."11 
While he was no prophet, obviously Bobrowski had identified the most important factor that distinguished the Belorussian from the Ukrainian or Romanian Uniate Churches. By the time a secular nationalist movement grew in Belorussia, the achievements of the Belorussian Uniate Church were no more. Thus, modern nationalism in Belorussia remained weak, at least in part because it lacked the nourishment rooted in a people's sense of sacredness and enduring values-their religion. Such roots provided strength to other groups experiencing a springtime of their nationhood in mid-nineteenth century, groups benefitted from the neutrality, if not support, of the Habsburg Empire. The Russian Empire in 1839 deliberately cut these roots and, over the next three decades or so, destroyed them.12 Nonetheless, the roots had existed. Their death was not an unavoidable phenomenon of nature. Thus Belorussia was denied the development of something that seemed natural to, or at least widespread in, Eastern Europe. The development of a church self-governing and autonomous, though perfectly loyal in most secular matters to the state in some far-off capital, that well expressed the sense of nationhood of a people, would not satisfy the aspirations of nationalists who require full state independence. But in an area of the world where everybody's homeland belonged also to some other nation living there too, a nationalism of the sort nourished by a Uniate Church might have promoted the progressive integration into a modern state that Methodists or Anglo-Irish-to return to our beginning comparisons-encouraged in the West.

That was not the question on the minds of many in the mid-nineteenth century. Aside from the obvious, expected, and ineffectual protests from the Vatican, the fate of the Uniate Church in Belorussia occasioned little reaction outside the Russian Empire. Furthermore, within the Empire the government's control of the press made public discussion, even praise of the government's actions, impossible. The situation changed in the era of "Great Reforms" after the death of Nicholas I and the calamitous defeat in the Crimean war. The situation changed only slowly, however. In the new climate of reform and openness in the 1860 s, the history of Catholicism in Russia by Dmitri Tolstoi, though written originally in Russian, was published in French in Paris in 1867. It was a decade later, after the 
suppression of Chelm, the last Uniate diocese in the empire, that the Russian edition appeared in St. Petersburg.

Toistoi's work inciuded a quite detailed account of the development and fate of the Uniate Church in Belorussia. The existence of the Uniate Church was a danger to Russia, he argued, for it was the instrument by which Poles subverted Russian nationalism among "West-Russians," resulting in the loss of these Russians to the Russian nation. Catherine the Great's government, which Tolstoi found praiseworthy in nearly every respect, understood that danger and effectively met it by carrying out the destruction of the Uniate Church. The government of Alexander I, lamentably, did not understand that danger, or much else. It undertook a disastrously mistaken program of westernizing reform that, among other grievous errors, allowed Roman Catholics, including special enemies such as Jesuits and Uniates, the freedom and scope to grow and increase their influence within the Empire, thus putting in peril the future of the nation. Fortunately, in Tolstoi's view, the government of Nicholas I realized the error and corrected it, suppressing the Uniates in $1839 .^{13}$

The era of "Counter-Reforms," in the 1880s, and in particular the fiftieth anniversary of the suppression/unification of 1839 , saw the rapid development of a large literature, both scholarly and popular, devoted to the history of the Uniate Church of Belorussia and in particular the events of 1839. This literature followed and expanded upon Tolstoi's interpretation of the significance of the Belorussian Uniate Church, adding to it a great deal of information, much of it in well edited document collections. ${ }^{14}$ This scholarly, if decidedly Russian nationalist, work on the history of the Uniate Church for all practical purposes was ended in the Soviet period. However, the Russian nationalist interpretation was challenged sharply by the only serious scholarly Soviet account. N. M. Nikolskii, a Bolshevik from Moscow appointed director of the Belorussian Academy of Sciences in Minsk, in 1931 published a history of the church in Russia with a discussion of the Uniates of Belorussia. Nikolskii argued that the unification of the Uniates with the Orthodox did not rescue the Belorussians from Polish oppression, but only replaced Polish with 
Russian oppressors. When Nikolskii's book was reprinted in 1983, the chapter on the Uniates was omitted, for, the editor explained, Nikolskii had misunderstood the significance of the 1839 unification in satisfying the "objective needs" of the Belorussians by uniting them with their brothers, the Russians. ${ }^{15}$

Suppressed in tsarist Russia and even more thoroughly crushed in the Soviet Union, Belorussian Uniates fared little better in the Polish Republic established after World War I. In 1922, the Treaty of Riga that concluded the Polish-Soviet War partitioned Belorussia between the Soviet Union and Poland, neither being willing to accept the declarations of independence made by some groups of Belorussian nationalists. These groups clearly lacked a public following that could be translated into the sort of armed strength that Lenin or Pilsudski would respect.

The concordat that the new Poland concluded with the Vatican in 1925 provided, at the Vatican's insistance, for the restoration of a Uniate hierarchy and with it the recognition of the legitimacy of an eastern-rite Catholic Church. The bishops of the Roman Catholic Church in Poland, who opposed Pilsudski and many other secular leaders on many issues, joined Pilsudski and others in efforts to thwart the autonomy of a Belorussian Catholic Church of either Latin or Eastern rite. While Belorussians launched many publications, few lasted beyond their inaugural issues, as Polish censorship laws quickly closed them down. One of the few successful Uniate journals that appeared in the Belorussian language was actually published by Jesuits While Polish suppression of Belorussian institutions, including the Uniate Church, did not match that of the Soviet government in brutality, it was nonetheless quite effective.

The Nazi "new order" in Eastern Europe apparently ended whatever slight hope remained for a viable Uniate Church in Belorussia. A Uniate priest, perhaps imagining that Nazi Germany would want to carry out the imperial German program of 1918, tried to persuade the Nazi occupation authorities that the Uniate Church should be recognized as the national church of Belorussia. Nazis were so wary of fostering autonomous states in Eastern Europe, even those friendly to Germany, that the priest was promptly arrested and shot. ${ }^{16}$ 
Given this bleak recent history, it is extraordinary that among the developments in Belorussia since the advent of glasnost and perestroika has been a revision of the old Russian-nationalist, anti-Uniate, scholarly literature on the Church to recover a past that nourishes aspirations for a native national church. The first issue of a new journal, Unia, published in Minsk in 1990, included a summary history of the Uniate Church in Belorussia, that made excellent use of the factual material provided by the Orthodox, tsarist historiography to reject that literature's interpretation of the significance of the Church while claiming the heritage of the Church for the Belorussian nation. One of the first issues of the bulletin of the Belorussian Democratic Union included an article arguing that the work of Father Bobrowski and the Vilna Seminary show how important the Church was for the development of a national language and how important the language, Belorussian, was for the Church. ${ }^{17}$ Thus, while the Orthodox Church in Belorussia is clearly identified as Russian, and the Roman Catholic Church is seen as Polish, the Uniate Church, particularly for the young, appears to have become an important institution for the nourishment of national consciousness in Belorussia. ${ }^{18}$

Belorussia was not at the center of the struggle against the tsarist state waged by national minorities seeking reform, if not political autonomy, in the late nineteenth and early twentieth centuries. ${ }^{19}$ Nonetheless, the Belorussia that was a constituent republic of the Union of Soviet Socialist Republics acquired both clearly marked state frontiers, and thus a definite homeland, and a literate, standard, modern form of its language. The history published in that language was not designed to promote aspirations for national autonomy, but to stress the ties that bound in a special way the brother nations of Russia, Belorussia, and Ukraine. While all churches were persecuted in the Soviet Union, the Uniates were attacked with special ferocity because a major point of Uniatism was its relationship with Rome and thus with the West, the home of the ideological and cultural as well as political and economic antithesis of the Soviet system. But because of the small number of Uniates in Belorussia, most Soviet propaganda against Uniates was aimed at the Church in Ukraine. 
The resurrection of the Uniate Church in Belorussia is not really comparable to developments in Ukraine or Romania, for in large measure it represents the development of a new institution rather than the growth of an old one. But, the deliberate, self-conscious way in which the eastern-rite Catholic Church identifies itself with the church that was crushed in 1839 shows not only the need for a history, a useful past, to sustain nation feeling, but also the tenacity of the concepts behind the union at its beginning. A people's sense of sacredness, their essentially religious commitment to values transcending their own time and nation, remain vital to their efforts both to make progressive change in their lives and to remain faithful to tradition for their own time and nation. 


\section{Notes}

1. For a superior introduction to the question, and to the modern literature devoted to it, see Christopher M. Hann, "Religion and Nationality in Central Europe: the Case of the Uniates," presented to London University conference, April 1989, and forthcoming in National Identity in Russia/USSR and Eastern Europe, W. Bracewell, ed. (London). My work for this paper has been generously supported by many. I wish to thank particularly the Russian Research Center of Harvard University, the National Endowment for the Humanities, and the Academic Computing Services of the University of Maine at Presque Isle.

2. Good examples include the work of my fellow contributors. See James P. Niessen, "Metropolitan Alexandru Sterca-Sulutiu in the National Movement," Studia Univ. Babes-Bolyai, Historia, XXXII (1987), 25-32; John-Paul Himka, "Priests and Peasants: the Greek-Catholic Pastor and the Ukrainian National Movement in Austria 1867-1900," Canadian Slavonic Papers, 21 (1979), 1-14. Two other particularly helpful studies are Keith Hitchins, "An East European Elite in the Eighteenth Century: the Romanian Uniate Hierarchy," The Rich, the Well Bom, and the Powerful, F.C. Jaher, ed. (Urbana, 1973), 139-53; Ivan L. Rudnytsky, "The Ukrainians in Galicia under Austrian Rule, "Nationbuilding and the Politics of Nationalism: Essays on Austrian Galicia, A.S. Markovits, F.E. Sysyn, eds. (Cambridge, 1982), 23-67.

3. An excellent summary of the extensive literature dealing with the fate of the Uniate Church in the Russian Empire is Igor Smolitsch, "Die Massnahmen gegen die Unierte Kirche," Geschichte der Russischen Kirche 1700-1917, II (Gregory L. Freeze, ed., Berlin, 1991), 390-421. For well balanced summaries, see Mark Elliot, "Uniates," Modern Enclyclopedia for Russian and Soviet History, 40 (1985), 210-19; David W. Edwards, "Orthodoxy During the Reign of Tsar Nicholas I: A Study in Church-State Relations" (Ph.D. dissertation, Kansas State University, 1967), 258-68. Of the many accounts of the formation of the Union of Brest, the best is Josef Macha, S.J., Ecclesiastical Unification: A Theoretical Framework together with Case Studies From The History of Latin-Byzantine Relations (Rome, 1974), 144-201. 
4. The standard Catholic treatments of the church under Catherine and Alexander I remain very useful. See Julian Pelesz, Geschichte der Union der Ruthenischen Kirche mit Rom von den ältesten Zeiten bis auf die Gegenwart (2v., Vienna, 1881); Edward Likowski, Dzieje kosciola unickiego na Litwie i Rusi w XVIII i XIX wieki (Poznan, 1880; 2nd ed. Warsaw, 1906). Pelesz was rector of the Uniate seminary in Vienna. Likowski was the Latin rite suffragan bishop of Poznan.

5. A clear, well documented account of the governance of the Church under Alexander I is Aleksey Petrani, Kolegium Duchowne w Petersburgu (Lublin, 1950), 39-48 ("Kolegium Duchowne Unickie"), 129-36 ("Sprawy Prowadzone w Kolegium Unickim"). Hieronim Eugeniusz Wyczawski, "Cerkiew Wschodnia na Terytorium (Archi)diecezji Wilenskiej," Studia Teologiczne 5-6 (1987-88) is much broader than the title suggests and provides a rich, up-to-date bibliography. It is worth noting that the term "Uniate" was the official designation for the church in Belorussia, but in the Habsburg domains that term was suppressed by Empress Maria Theresa in 1774, replaced by "Greek Catholic," in an effort to assert the legal and moral equality of the church with the Roman (i.e. Latin-rite, Polish) Catholic Church.

6. Within the very large historical literature devoted to nationalism it may be useful to focus on "nation-building" as an essential step in, or synonym for, a crucial aspect of modernization. For a rich discussion, see Cyril E. Black, The Dynamics of Modernization: a Study in Comparative History (New York, 1966), a work long out of print but which repays re-reading. My thinking about the Uniate churches in Eastern Europe owes much also to the sophistication enriching much recent work on the Roman Catholic Church in Ireland-another church of peasants who lived in a multinational empire and developed a modern sense of nationality over the course of the nineteenth century. For a learned discussion of the literature, see Patrick Corish, The Irish Catholic Experience: a Historical Survey (Dublin, 1985), especially chapter 6, "The Waning of 'Old Ireland'. " It should be noted also that many able scholars discuss the rise of nationalism in the eighteenth and early nineteenth century without finding it useful to mention any church or religion at all. See, for example, Liah Greenfeld, "The Formation of the Russian National Identity: The Role of Status Insecurity and Ressentiment," Comparative Studies in Society and History, 32 (1990), 549-91. 
7. It is of interest that the Romanian Uniates also rejected the appointment of bishops from the Ruthenian (i.e., Ukrainian) Uniate Church, for the same reasons and with the same vehemence that they opposed the appointment of Germans or Hungarians or, for that matter, of Romans. Keith Hitchins, "Religious Tradition and National Consciousness Among the Romanians of Transylvania, 1730-1780, " Harvard Ukrainian Studies, X (1986), 555-56.

8. For a particularly well focused discussion of this point, see John-Paul Himka, "The Greek Catholic Church and Nation-Building in Galicia, 1772-1918, "Harvard Ukrainian Studies, VIII (1984), 442-52.

9. Daniel Beauvois, "Les Lumieries au carrefour de L'Orthodoxie et du Catholicisme: Le cas des uniates de l'Empire russe au debut du XIXe siecle," Cahiers du Monde russe et sovietique, XIX (1978), 423-41, is an admirably well informed discussion of these matters, though concluding that the enlightened in the end were too few, and too thoroughly beaten by reaction, to count as successful.

10. For details, see J. T. Flynn, "The Affair of Kostomarov's Dissertation: A Case Study of Official Nationalism in Practice," The Slavonic and East European Review, LII (1974), 188-96.

11. "Vzgliad prof. prot. M. K. Bobrovskago na obshchii khod uniatskago voprosa v XIX veke," Khristianskoe chtenie 1907, 773-74. For biographical information on Bobrowski, see Walerjan Charkiewicz, "Bobrowski, " Polski slownik biograficzny, II (Krakow, 1936), 160-61; V. Shtein, "Bobrovskii," Russkii biograficheskii slovar, III (St.Petersburg, 1908), 120-23.

12. Although it had little direct relevance for the fate of the Belorussian Uniate Church, there did remain a Uniate Church in the empire. In the southeast of Congress Kingdom Poland (renamed "Vistula Region" in consequence of the Polish revolt of 1863), the Uniate diocese of Chelm, part of the Habsburg Empire transfered to Russia by the Congress of Vienna in 1815, continued to function until it was suppressed in 1875. This church continued to show signs of life, especially since many of its adherents refused to attend Orthodox services despite considerable government pressure to do so. After religious toleration was 
won by the 1905 revolution, there were mass conversions to Roman Catholicism, since the empire's new tolerance did not extend so far as to include Uniates. This development was perceived as dangerous for the Russian Empire not only by Stolypin and the tsar's government but also by the new parliament won by the 1905 revolution, the Duma. The Duma passed legislation to make a new province of the Chelm district and to transfer it to the governor-generalship of Kiev, in order to facilitate defense of Orthodoxy and, thereby, of Russification. For thorough discussion of these developments, see Edward Chmielewski, The Polish Question in the Russian State Duma (Knoxville, 1970), 111-134.

13. D. A. Tolstoi, Le Catholicisme Romain en Russe (2 v., Paris, 1864), II, 330-82; Rimskii katolisizm v Rossii (2 v., St. Petersburg, 1876-77). Tolstoi's work provided not only an interpretation, but also a fund of detailed information that was much used by, among others, the Catholic scholars who took up the Uniate topic soon thereafter. See the works of Pelesz and Likowski, cited in note 4 above.

14. Among the most important are Iosif [Semashko], Zapiski Iosifa Mitropolita Litovskago (3 v., St.Petersburg, 1883); the history of the Vilna Seminary by P.N. Zhukovich, serialized with various titles in Khristianskoe chtenie (1887), 237-86, (1888), 367-409 and 556-95, (1892), 362-98; P. O. Bobrovskii, "Russkaia greko-uniatskaia tserkov v tsarstvovanie imperatora Aleksandra I," Zhurnal ministerstva narodnago prosveshcheniia serialized in volumes $263-267$ (1889-90)

15. N. M. Nikolskii, Istoriia russkoi tserkvi (3rd ed., Moscow, 1983). The editor, N. S. Gordienko, explaining the ommission of Nikolskii's chapter on the Uniates, wrote (p.18) that "the liquidation of the uniates... answered the true fundamental interests of the popular masses of Ukraine, Belorussia, and Russia." Nikolskii's first two editions (both Moscow 1931) differ only in the preface, not the text.

16. Detailed studies of the fate of Belorussia in the twentieth century are Ivan S. Lubachko, Belorussia under Soviet Rule 1917-1957 (Lexington, 1972) and Jan T. Gross, Revolution From Abroad: The Soviet Conquest of Poland's Western Ukraine and Western Belorussia (Princeton, 1988), although neither pays more than incidental attention to Uniates or religion. 
17. Aleg Latyshonak, "Belastochyna i narodzini belauskae dumki," Belaruskiia Naviny (1991), 2, 20-24.

18. This conclusion is reached by many observers. See interview with Vintsuk Vyachorka, secretary of the Belorussian Popular Front (BFL), in "Citadel of Communism," Uncaptive Minds IV, No. 3 (Fall, 1991), especially 48 and 51.

19. Thus, Violet Conolly, "The 'nationalities question' in the last phase of tsardom, "Russia Enters the Twentieth Century.1894-1917 (E. Oberlander, ed., New York, 1971), 152-81, finds it unnecessary to mention Belorussia at all. Nicholas P. Vakar, Belorussia: The Making of a Nation (Cambridge, 1956) remains the most useful survey of the development of Belorussian nationalism. 


\section{The Greek Catholic Church and the Romanian \\ Nation in Transylvania}

\section{James Niessen}

During most of the period since the mid-eighteenth century, Transylvanian Romanian society (itself constituting roughly one third of the nation) has been divided into two major ecclesiastic communities, the Orthodox and the Greek Catholics.' Romanians as a whole are predominantly Orthodox. This fact and the collaboration of the Orthodox church with the Romanian state, especially after 1918, have led many to assert that Orthodoxy was and remains the primary characteristic of Romanian ethnic and national identity. Orthodox Romanians have sometimes portrayed the Greek Catholics' church union as extrinsic to native traditions and destructive of national unity. ${ }^{2}$ In fact, Greek Catholics have made a positive and continuing contribution to nation-building. The fact of foreign influence in this church was not unique among Romanian churches, since Orthodoxy's survival was also due, in part, to foreign (Greek, Russian, and Serbian) support. ${ }^{3}$

"Nation" had a specific meaning in Transylvanian political tradition: a privileged social stratum whose name (Hungarian, Szekler, or Saxon) coincidentally denoted the larger ethnic group of which it was a part. Romanian nation-builders aspired in the eighteenth century to attain this status for the Romanian clergy, and only later for all Romanians in Transylvania. Due to political realities, the demand for the unification of the Romanians in all the states where they lived was raised still later. Both Romanian churches made important contributions to this process.

Transylvanian Romanians were for a long time almost completely lacking in secular political leadership. When it was concluded in 1698 , the Romanian church 
union initially enjoyed the support of almost all the Orthodox clergy of Transylvania, who were promised better educational opportunities for their people and the granting of the same noble status enjoyed by the rest of the Catholic clergy in Transylvania. They never realized the second of these promises, and educational improvements were slow in coming. The Habsburg authorities sought by the union to strengthen the loyal Catholic element in Transylvania and to counterbalance the influence of the Hungarian Protestant estates. The Diet, however, successfully blocked the granting of privileged status for the Greek Catholic clergy.

We can identify two rival tendencies among bishops and clergy in the first two centuries of the Romanian church union. On one hand was the "Latinizing" trend inspired by the suspicion toward Romanian "orientals" on the part of the Austrian authorities and Hungarian episcopate. They provided for the supervision of the Romanian bishops by a teologus of the Latin rite, subordinated them to the Hungarian Primate of Esztergom, and favored an absolutistic form of administration and the celibate clergy who were products of Hungarian seminaries. Opposing this tendency were the "easternizers" who protested these policies and demanded a resolutely Romanian church with strict preservation of eastern practices like regular synods, protopopal jurisdiction, and a married clergy. ${ }^{4}$ This easternizing trend thus appeared earlier than among the Galician Ukrainians (see the study by John-Paul Himka in this volume). In both cases relations with the surviving Orthodox community stimulated it, but the Russophile component was far weaker in Transylvania. The competition of Latinizers and easternizers posed many conflicts for the Romanian bishops, three of whom were forced to resign-in 1751, 1782, and 1850.

The union faced the first major threat to its existence in the mid-eighteenth century as the result of the disappointment of clerical expectations, demographic change, and Serbian and Russian influence. Bishop Ion Inochentie Micu-Klein wrote letters and organized meetings to protest the failure to improve the social status of his clergy, leading Austrian authorities to depose him in 1751. The unsettled state of Transylvanian society, only recently occupied by Austria, buffeted by changes in 
fiscal policy and massive colonization of adjacent territories, and possibly even by an influx of Romanian Orthodox settlers from the Danubian principalities, simultaneously weakened the hold of the Catholic clergy on its flock, which was already restive and suspicious of the religious "innovations." ${ }^{\text {s }}$ Finally, the crucial spark for an Orthodox uprising in 1758-62 was the support given the rebels by the Serbian church hierarchy in southern Hungary and Russian diplomats. The precedence of religious over ethnic solidarity in the movement prompts Emanuel Turczynski to speak in this context of a Serbian-Romanian confessional nationality ${ }^{6}$. The monasteries and hermitages of clergymen who had abandoned the church union were the centers of the uprising, and suffered widespread destruction by Austrian artillery in the course of the suppression of the uprising. Romanian monasticism in Transylvania never recovered completely.

The church union survived the upheaval, badly shaken. According to an Austrian tabulation in 1762, only one-sixth of Transylvanian Romanian families were Greek Catholic in that year, and the remainder Orthodox. ${ }^{7}$ The state reluctantly recognized the reestablishment of a network of Orthodox parishes, and placed them under the authority of a Serbian bishop residing in Hungary. The violence of the struggle that preceded these concessions left many Orthodox with the conviction that Romanian Catholicism survived primarily by virtue of Austrian military might.

In the wake of the uprising, Greek Catholic life gained a new, firmer basis that was of greater significance for the future of the divided nation than the concessions granted to the Orthodox. Klein established an impressive new cathedral in Blaj, completed in 1749. Romanian clergymen had begun to enjoy access to Catholic seminaries in the Habsburg lands (with Hungarians in Hungary, and with Ukrainians at St. Barbara's in Vienna), and even in Rome. These beneficiaries of advanced training staffed four new schools established by the Greek Catholic bishop at his diocesan seat in Blaj in central Transylvania, between 1754 and 1760 . Over the next twenty years, the seminaries and other schools in Blaj instructed an average of 300 pupils each year. These were the first schools to teach Romanians in such large numbers and at an advanced level. A second generation of foreign-educated 
clergymen extended the school system into the villages, where 300 elementary schools were established between 1782 and $1794 .{ }^{8}$

These schoois initiated the spread of a nationai, literate culture that would eventually transform the prenational culture of peasant villagers. Under Bishop Gregorie Maior (1772-82) the educational expansion was accompanied by proselytism so successful it alarmed Hungarian leaders who, fearful of a renewed threat to the religious balance, forced his resignation. More immediately significant was the new national ideology formulated by several of Maior's protegés that came to inspire the teachers in Blaj and the graduates of its seminaries.

Greek Catholics studying in Vienna and Rome were impressed by the similarity of the Romanian and the Latin languages. Convinced that the church union constituted the return of the Romanians to their original form of Christianity, they developed existing theories of the Romanians' Roman origins and their own historic and linguistic research into a national ideology. The Romanians used their historical priority to demand recognition as a fourth nation in the Transylvanian Diet. ${ }^{9}$ The works of these writers, whom Romanian historians know collectively as the Transylvanian School, began to appear in the 1770s, contributing to the assault on the Hungarian estates' privileges by Austrian absolutism. In 1791 and 1792 Romanian leaders submitted to the emperor two appeals for the recognition of Romanian rights, entitled Supplex Libellus Valachorum, that were based on these writings. The participation of Romanian Orthodox in these unsuccessful appeals demonstrates that the new ideology had found adherents in both communities. ${ }^{10}$

The schools of Blaj played the leading role in the Romanian awakening in the decades prior to 1848 . The seminaries and high school of Blaj were the only Romanian institutions teaching at this level. When the governor of Transylvania, Baron Bánffy, learned in 1808 that there were more than 200 Romanians studying in Blaj, he asked Bishop Ioan Bob (1783-1830) suspiciously what he hoped to achieve "by maintaining so many individuals in your schools who can become dangerous for the country?"II The students came primarily from the Greek Catholic community, which consisted chiefly of the serfs of the Hungarian landlords, but a significant 
minority were Orthodox. Nearly 11,000 Romanians studied at the schools of Blaj between 1754 and 1848. There are strikingly few leaders of the Transylvanian Romanian awakening and the struggles of $1848-49$ who did not study in Blaj at one time or another. ${ }^{12}$

Both Bishop Bob and his successor Ioan Lemeni (1830-50) were wary of their intellectuals, but for a different reason than Baron Bánffy. The writings of the Transylvanian School were popular among Romanian students, even in the second Romanian Uniate diocese at Oradea in Hungary proper, founded in 1777. (Here, as at the seminary in Vilna, youth of the eastern rite studied together with the more privileged Latin-rite sons of the dominant nationality; see the study in this volume by James Flynn). Bob's harshest critic was a leader of the Transylvanian School, Petru Maior. His History of the Romanian Church (1813) was an anti-Latinist manifesto, asserting that Romanians "had only accepted the Union with Rome on condition that no Popish custom should ever be imposed on them by their own Bishop, or, much less so, by foreigners." Bob banned it, and confiscated the copies that had not been distributed. ${ }^{13}$ While Romanian replaced Latin as the language of instruction in Blaj during Lemeni's tenure, he at one time considered replacing it with Hungarian. Between 1842 and 1846 he became embroiled in a controversy with several radical professors at the high school, whom he finally banned with the approval of the ecclesiastic court of appeal in Esztergom.

One of the former professors, Simion Bărnuţiu, would become the ideological spokesman of the Romanian revolution of 1848-9. The Romanian bishops had repeatedly proposed to convene church synods that would simultaneously serve as a public forum for national grievances against the Hungarians and enhance their own churches' position. Barnuţiu went beyond this in 1843 to propose that the synod include the laity, as well. In May, 1848, he delivered a seminal speech to the crowd assembled in Blaj, in which he denounced the union as having been "with the Hungarians and not with Rome," a cruel trick that enslaved half the nation, impoverished the rest, and set the two halves against each other. One bad union should not be followed by another, he added, calling upon the listeners to reject the 
proposed union of Transylvania with Hungary. The assembly adopted the antiLatinist program, demanding an independent and united Romanian church with annual synods and popular participation in them but neglecting to attach a confessional label to the united church. ${ }^{14}$

The Orthodox bishop, Andreiu Şaguna, was a forceful and ambitious man, but too conservative to take advantage of this decision. By contrast Lemeni, a far less decisive statesman, discredited himself at the court through his sympathy for the Hungarians, and was forced to abdicate in 1850 after they had been defeated in their uprising in 1849. Repeated Romanian delegations to Vienna, Uniate or Orthodox, now demanded hierarchical emancipation, or a metropolitanate, for their church. The Uniates succeeded first, in 1855, the year of the Austrian concordat, when the church in Austria was emancipated from Josephinism. The church province of Blaj, no longer subject to Esztergom, was subordinated directly to the Holy See, with suffragan bishoprics in Gherla, Lugoj, and Oradea. The new metropolitan, Alexandru Sterca-Şuluţiu (1851-67), hoped, in a period when Austria was extending its influence in the Danubian principalities, to benefit by extending his own church into these areas. As he stated in a pastoral letter, the union of Romanians beyond the Carpathians with the Holy See would permanently ally their fate with the western powers. Saguna succeeded later, only in 1864 , in gaining emancipation from the Serbian church. The act was a reward for his loyalty to the imperial government and not an indication of any official sympathy for his church. ${ }^{15}$

The Romanian bishops cooperated in the interest of the nation in the secular politics of the 1860s. Seeking to defeat the Hungarian opposition, Austria enacted a new electoral law in 1863 that increased the electorate by a factor of nine, giving Romanians effective control of the vote in Transylvania counties, where the dominion of the Hungarian nobility had long been unchallenged. Faced with the opportunity to gain a large share of deputies for the first time, the Romanian bishops agreed upon the slate of Romanian candidates and worked together with their clergy to get out the vote in the rural districts. The official voting records show that the clergy was remarkably successful, securing more than 80 percent voter participation and the 
election of Romanian candidates in the Romanian countryside. Şaguna and StercaŞuluţiu both led delegations to Vienna to present Romanian petitions, served as the chief Romanian spokesmen in the provincial conference of 1861 and diet of 1863-64, and represented their people in the imperial parliament in Vienna. ${ }^{16}$ Thus, the activity of the clergy of both rites contributed in a very concrete sense to the formation of a politically active nation that transcended traditional narrow elites.

Sterca-Şuluţiu was not only a Romanian militant, but the bishop most closely associated with the easternizing)tendency in the Uniate Church. In his presentations to Rome, he repeatedly defended oriental canon law, or the Pravila, but with mitigated success. Following a denunciation by a Latin-rite Hungarian priest, the Holy See reprimanded Şuluţiu for participating in a liturgy with Şaguna, branding his act communicatio in divinis cum haereticis et schismaticis. Şulufiu protested in the Hungarian press that "the Latin mother church itself recognizes that the clergy of the Greek non-united is good and valid, and possesses apostolic succession, that it celebrates a true liturgy, that it administers the seven sacraments validly, etc." Displeased by this "premature" ecumenism, Rome considered appointing a coadjutor who would assume most of Şulufiu's powers. ${ }^{17}$

The Austro-Hungarian Compromise of 1867 found the two Romanian religious communities in Transylvania roughly equal in size and number of schools, and with church hierarchies of equal status and independence. The Compromise also brought to an end the period of greatest clerical involvement in politics. Economic development as well as educational achievements meant that the clergy no longer dominated the Romanian intelligentsia as it had earlier in the century. The declining influence of the clergy was a universal phenomenon in Hungarian society. ${ }^{18}$ As the other studies in this volume demonstrate, the clergy had provided intellectual and political leadership for a peasant nation in conflict with an alien nobility. But the Romanian leadership was more resolutely biconfessional than that of the Galician Ukrainians, and generally worked well with the episcopate. This helps explain the relative rareness of anticlericalism in both Romanian religious communities. 
The churches remained important national institutions, despite the secularizing trend, because their preaching and schools provided a bulwark against Af increasingly nationalistic Hungarian policies. Hungarian law recognized the autonomy of these churches, and both the emperor and the Holy See took a special interest in the Uniates. After 1864 the Romanian Orthodox of Transylvania and Hungary gained not only emancipation from the Serbian hierarchy, but also the achievement of an old goal of the Greek Catholic authors of the Transylvanian School: the establishment of representative bodies, with sizable lay membership, for the administration of many church matters. The elective "National Church Congress" of the Orthodox provided the stage for animated debates on Hungarian school and church policies, and the Orthodox also cultivated more institutional contacts with Romanians across the Carpathians than did the Uniates. ${ }^{19}$

The representative system of the Orthodox posed a political challenge for Greek Catholic leaders. The adherents of Şulutiu remained powerful in the clergy, although their brief support for the candidacy of Napoleon III's nephew Lucien, a French cardinal, as metropolitan demonstrates their primary inspiration was nationalism rather than strict easternism. Şulufiu's successor, Ioan Vancea (186892), was a theological moderate who sought to improve relations with the Latin rite. Vancea convened several mixed congresses, to regulate the schools and clerical income, and synods between 1869 and 1882 . Easternizers at the assemblies sought to reinforce the legislative and electoral prerogative of the synod and broaden its membership, but the Propaganda Congregation rejected many of the decisions of the synods. As finally promulgated, the synodal decrees instituted minor revisions in liturgy and discipline and a statement of the faith which brought Greek Catholic practices closer to those of Rome. ${ }^{20}$

As in the case of the Galician Ukrainian church, forceful action by the Vatican tamed an incipient easternist revolt. Subsequently easternizers within the Uniate clergy became fewer. Militants saw this clerical moderation as evidence of Hungarian influence. Not only did Hungarian governments have a say in the nomination of bishops (this was true of the Orthodox bishops as well), but Uniate 
bishops participated in the Hungarian Catholic Bishops' Conference (püspöki kar), which for many Hungarians embodied the integrity of the lands of the Holy Crown of St. Stephen. Hungarians in the Catholic Autonomy movement, which sought to create a representative system for their church rather similar to that of the Romanian Orthodox, hoped to include the Uniates in it. The Romanian laity and their bishops repeatedly rejected these proposals when they became more insistent at the turn of the century. Undeniably, however, the common theological training of many members of the clergy, and a modest convergence of religious practice in the veneration of statuary and of certain saints, even the frequenting of some of the same shrines, created sympathy between Hungarians and Romanian Uniates despite the difference of rite and their tense secular political relations.

The reality of ethnic assimilation stimulated the easternism of Romanian nationalists who saw religious rapprochement as a dangerous Trojan horse. Most Greek Catholics on Hungarian territory identified themselves as Romanians or Ruthenians (i.e., Rusyns) in the Hungarian census. The number of Hungarian Greek Catholics doubled between 1880 and 1910, primarily in eastern Hungary proper rather than Transylvania. The magyarization of Rusyns and, to a much lesser extent, of Romanians was partly the consequence of the ecclesiastic influences noted above. The chief reason for their assimilation, however, was their location at the edge of the area of Rusyn or Romanian habitation, or even surrounded by Hungarians, living in small, scattered communities and frequently unable to afford to maintain their own schools. ${ }^{21}$

During the Dualist period a movement arose among Hungarian Greek Catholics for the creation of a separate Hungarian diocese. From the turn of the century the Hungarian government supported their request, which was finally granted by a papal bull in 1912. Of the 162 parishes in the new diocese of Hajdúdorog, which still exists in Hungary today, more than half were taken from Romanian dioceses. The Romanian bishops joined the widespread public protests of Romanian Uniates and Orthodox when the large number of Romanians involved became known. Individual Hungarians and the government were the prime movers in creating the 
diocese, and the Holy See agreed to it for primarily political reasons; the government was also considering the creation of a Hungarian Orthodox bishopric on the eve of World War I. ${ }^{22}$

Peter Sugar has identified $1848-1914$ as the second period in the history of East European nationalism, the one in which the exclusion of purported enemies' influence was a principal preoccupation of the nation-builders. ${ }^{23}$ Greek Catholics had propagated a national ideology and a political struggle directed largely against the Hungarians since the eighteenth century, whereas the Romanian Orthodox of the Hungarian lands had been preoccupied with institutional survival, then emancipation from Serbian tutelage. The repressive character of the dualist system after 1867 increasingly directed Romanian animosity toward the Hungarian state, and thus the Greek Catholics' brand of nationalism became standard. Greek Catholic laymen were prominent in the Romanian National Party of Hungary, including its leading personality, Iuliu Maniu, who also served as attorney of the Metropolitan in Blaj. The Greek Catholic schools did not dominate local Romanian culture to the same degree as earlier, but retained a symbolic leadership. This helps to explain a remark one contemporary made about Ágoston Trefort, Hungarian Minister of Religion and Education, in the 1880s: "Every time he hears the name Blaj, he shivers. "24

The culture of Blaj, in contrast with Orthodoxy, embodied a link with the WWest as well as resistance to the Hungarians. Russophobia and a suspicion of the Orthodox Church complemented each other in Austria and Hungary. In documented cases, Transylvanian officials treated Orthodox monks and even nuns from across the Carpathians as spies. It was mistakenly reported that calugări [Romanian for monks] were so named because of their ties to the Russian monastery at Kaluga, and were employed in spreading incendiary tsarist ukazes. ${ }^{25}$ In truth Romanian patriots bore little love for Russia after its annexation of Bessarabia in 1812 and its suppression of the Wallachian revolution in 1848. The Orthodox Church was subordinated to the state in both Russia and the Romanian Kingdom, and indeed was far less free in Romania prior to 1914 than in Hungary. The Greek Catholic historian Augustin Bunea clearly had this in mind when he predicted in 1903 : 
If Romania should ever come to be ruled by Moscow...may God protect us.... Then it will be seen what a powerful instrument for denationalization the Orthodox Church is, whose head is the holy Tsar. ${ }^{26}$

Bunea correctly foresaw the dangerous implications for his church of Russia's patronage of Orthodoxy. He underestimated the indigenous character of Orthodoxy, and he had no intimation of how it might relate to communism.

Between 1848 and 1914, the center of gravity of Romanian politics and culture shifted to the Danubian principalities, which united in 1862 and became independent Romania in 1878. Romanian nationalism in this context emphasized different themes than it did under Hungarian rule. Foremost among them were the consolidation of state power and, increasingly, the centrality of Orthodoxy for national culture. Few Greek Catholics lived in Romania prior to 1914, and their first parish in Bucharest was organized only in 1910, in the face of considerable public protest. Still, Romanian Greek Catholic leaders were no slower than the Orthodox to welcome the creation of Greater Romania at the end of 1918 . In an act with powerful symbolism, the Orthodox Bishop of Caransebes in the Banat, Miron Cristea, and the Greek Catholic Bishop of Gherla, Iuliu Hossu (1917-1970), jointly officiated at the popular assembly at Alba Iulia that proclaimed the unification of Transylvania with Romania in December, 1918.

The Greek Catholic Church and its lay politicians were eager, indeed indispensable partners in the immediate task of consolidating Romanian control over the newly annexed former Hungarian lands. The Greek Catholic bishops of the Rusyns, now subjects of Czechoslovakia, viewed their new rulers with hostility, ${ }^{27}$ but their eastern-rite colleagues in Romania welcomed Romanian rule. Transylvanian Romanians oversaw the replacement of the Hungarian administration by a Romanian one during 1919-20, and participated in the coalition government in Bucharest in this period. The Constitution of 1923 restated the clause in the Constitution of 1866 to the effect that the Orthodox Church was "the first religion in the state," adding that the Greek Catholic Church was also a national church, enjoying precedence (a 
precedence it did not define) over all the other churches-i.e., those of the ethnic minorities. Greek Catholics and Orthodox both benefited from subsidies and administrative measures that made possible the construction, for the first time, of monumental Romanian churches in the centers of most Transylvanian cities.

The collaboration of the churches, while continuing until 1948, became more difficult with the rise of a new variant of Romanian nationalism associated with Orthodoxy in the two decades preceding World War II. ${ }^{28}$ Prior to the Depression, the spur to religious rivalry in politics was the task of integrating the new lands into the administration and politics of the expanded state. The ecclesiastic integration of the Orthodox Church through the creation of the Romanian Patriarchate (Miron Cristea became its first titulary) and accompanying statute in 1925 aroused little controversy; Romanian Orthodox autocephaly had already been attained in 1882 . The proposal of a concordat with the Holy See, designed to eliminate the authority of bishops in Hungary from Romanian territory and guarantee that of Catholic bishops in Romania, was another matter. Catholic bishops of both rites supported it, while the Orthodox bishops and many members of the governing party opposed it. A proposed law on religion, meant to facilitate the concordat, provoked Greek Catholic protests by establishing the principle that in the event of mass conversion the property of a parish would pass to the church whose members were most numerous. Catholic canon law maintains that the disposition of parish property is the prerogative of bishops. In response to an appeal by their bishops, Greek Catholic clergy led massive protests in several Transylvanian cities against the proposed article in the spring of 1928. Violent clashes with the police took place, and the Senate's debate on the law featured impassioned speeches by luliu Hossu, Miron Cristea, and Nicolae Bălan, the Orthodox Metropolitan of Transylvania. ${ }^{29}$ The result was the omission of the controversial article and the final approval in 1929, under a new government, of the concordat. Among other things, this concordat ratified the retrocession of the 75 parishes in the diocese of Hajdúdorog that were on Romanian territory. 
The more extreme Orthodoxism of Romanian nationalists in the 1930s was less clearly linked to institutional religion. Many writers, repudiating western political forms and culture, argued that the collectivist and mystical spirit of peasants' Orthodox faith ought to be the basis of Romanian public life. The political activist Corneliu Zelea Codreanu preached similar ideas in the Legion of the Archangel Michael, a violent yet idealistic fascist movement. At its electoral high point, in 1937, it drew support from all Romanian regions of the country except those where Greek Catholics were most numerous. ${ }^{30}$

In this ultranationalist climate, the call for religious reunification struck many as a way to weaken the Hungarian danger. At a rather futile conference on religious reunification held at Alba Iulia in February, 1939 with the blessing of Metropolitans Bălan and the Uniate Nicolescu, many distinguished intellectuals delivered fervent pleas for union under the aegis of one church or another. They agreed that unity was urgently needed, but presented rival solutions in the nation's return to its Orthodox or its Latin roots ${ }^{31}$

After 1945, communists branded their opponents-Orthodox and Greek Catholics, nationalists and moderates-as war criminals. The Orthodox, being somewhat more culpable, sought to shift the attention to the Uniates' behavior. Uniates like Iuliu Maniu had spent the war years far from the center of power, while their bishops' patriotism was repeatedly questioned, particularly because several, led by Iuliu Hossu, took part in the Hungarian Catholic Bishops' conference after the territory of their sees was reannexed by Hungary in 1940. Hossu participated in every session of the conference between 1940 and 1944, actually employing the oratorical ability he had demonstrated in 1918 and 1928 to protest measures taken against the Romanian minority. A young Greek Catholic priest, Alexandru Todea, wrote an obituary of Metropolitan Nicolescu in 1941 in which he defended him against the charge of insufficient "nationalism." Patriarch Justinian Marina would later absurdly claim that "the Pope and Mussolini gave Northern Transylvania to the Hungarians because the majority there were Greek Catholics and the Greek Catholics prefer to look toward Budapest rather than Bucharest. ${ }^{n 2}$ 
Patriotism had gained a new meaning in Romania by 1948: all ties with the West were suspect. A year after the suppression of the Ukrainian Uniates and following a visit to Bucharest by the Russian Patriarch, the assault on the Catholics began. Following public appeals by Marina and Metropolitan Bălan, 430 Uniate priests (out of 1800) endorsed reunification and staged a putative synod on October 1, 1948 that solemnly proclaimed the reunification of their church and its one and a half million members with the Orthodox. None of the Uniate bishops adhered to this act, and Bishop Hossu anathematized the Uniate deans who participated. All bishops were deposed and arrested, imprisoned, sentenced to hard labor, or interned in Orthodox monasteries, together with more than 600 priests. Of the bishops, only Iuliu Hossu survived his sentence. Two years before his death in 1970, Pope Paul $X$ VI secretly named him the first Romanian cardinal. ${ }^{33}$

The common experience of repression among Greek Catholics and Hungarian Roman Catholics reinforced their historical ties. Áron Márton, Bishop of Alba Iuliâ 1936-1980, had courageously protested against his fellow Hungarians' mistreatment of Jews and Romanians in Northern Transylvania during World War II. He also condemned the suppression of the Greek Catholics, and welcomed their attendance of his own churches, before being himself arrested. The continued operation of the Hungarian parishes, albeit under harsh conditions, was an important solace for Greek Catholics. Several Hungarian and Romania bishops shared prison cells, including Alexandru Todea, whom the Papal Nuncio had secretly consecrated in 1950. Todea shared a cell with Márton and other Hungarian bishops in 1952-55, developing an uncommon rapport and mutual understanding with them in this period. This rapport was particularly important in subsequent decades when both rejected concessions from the communists that would have come at the expense of the other nationality. The letter to Pope John Paul II by Greek Catholic dissident Doina Cornea, read on Radio Free Europe in 1988, is characteristic of this attitude. ${ }^{34}$

After years of imprisonment and service as an "underground" bishop of his church, Todea was secretly elected Metropolitan in 1986. Romanian democrats, a disproportionate number of whom belonged to the Greek Catholic minority, were 
unanimous in considering the act of 1948 illegal. Following the sudden overthrow of Romanian communism at the end of 1989 , the church was legalized. Todea convened his colleagues on January 8, 1990. Their public statement included the declaration:

The Romanian Uniate Church is...the institution of Latinity of the Romanian people....The Romanian Uniate Church is a religious, but also a national institution. Because it is Catholic, it loves its people first of all, but addresses it, through its Catholicity, in a European and universalist spirit. $^{35}$

This universalist spirit is a difficult challenge for Greek Catholics in the conditions of contemporary Romania. Orthodox bishops and laymen, particularly nationalist extremists, have raised old charges of treason against their religious rivals. These same people expressed consternation when John Paul II admonished Romanian pilgrims visiting the Uniate shrine at Máriapócs in Hungary in August, 1991, in Romanian, to maintain "good relations with all Christians and peoples, including your land's ethnic minorities. " ${ }^{36}$ )

In a striking parallel to the 1920s, Greek Catholic laymen in Transylvania have expressed strong support for the political opposition, while their adversaries have defended governmental authority and the dominance of the Orthodox Church. Again reminiscent of the 1920s, Todea and his colleagues quickly denounced as uncanonicab a government-sponsored "compromise proposal" in 1990 by which, as had been proposed in 1928, the disposition of parish property would be determined $\checkmark$ by local voting. By March, 1992, Greek Catholics had still recovered on 48 churches, far fewer than in Ukraine. Liturgies took place in public places or in (x buildings designed for other purposes. Demanding the return of all churches, Metropolitan (now Cardinal) Todea stated to a crowd of worshipers in the central square of Cluj in September, 1991 that "the Romanian Uniate Church considers itself- $f$ to be persecuted in Romania by other Romanians. " ${ }^{37}$ But the bishops' insistence 
upon restitutio in integrum of the confiscated churches, while correct in principle, has had timited results. The Greek Catholics have recovered two historic cathedrals, in Lugoj through the good will of the local Orthodox metropolitan, Nicolae Corneanu, and in Blaj after the Orthodox pastor announced his conversion and turned the church over to Todea. Worshippers in several rural localities have suffered violent acts of intimidation. With rare exceptions the mass media have presented only the Orthodox viewpoint, including the declaration by Patriarch Teoctist Arăpaşu in 1991 after the return of the cathedral in Blaj that his church would break off the ecumenical dialogue with the Vatican because of its aggression. President lliescu appears to be partial to the Orthodox side. ${ }^{38}$

One of the powerful recurrent themes of the Greek Catholics' revival since 1985 has been the affirmation of ties to the West and the essential unity of European culture. Pope John Paul II invoked this theme once again in addressing the pilgrims at Máriapócs in Italian, Hungarian, Ukrainian, Slovak, Rusyn, and Romanian. For Romanians, the idea of Latinity adds extra significance to the Roman church.

The resurgence of the Greek Catholics has thus far been more successful in Ukraine than in Romania. Why is this the case? Two substantial reasons on the Ukrainian side are the fact that Greek Catholics constitute a far higher percentage of the population in their native region and, as our studies demonstrate, Ukrainian Catholics have played a more central role for the survival of their nation in our century. Almost all Romanians lived in their own national state after 1918. Orthodoxy has had a rising importance for the dominant strain of nationalism, and unlike the Ukrainian Orthodox Church the Romanian Orthodox Church early established its autocephaly, indeed a flourishing system of seminaries and publications that developed further in the communist period. Since 1989 the Orthodox have called the Greek Catholics' patriotism into question, with considerable success. The outcome will have much to do with secular domestic and international issues. In all three borderland nations, Belorussia, Ukraine, and Romania, the contest between East and West for women's and men's souls has become public once again. 


\section{Notes}

1. For the period before 1918 I use "Transylvania" for the territory of this principality. Many Romanians resided to the west of Transylvania, and where necessary the broader term "Hungary" is employed. All territory of Hungary ceded to Romania in 1920 is commonly referred to as Transylvania in the later period. This study benefitted from a scholarship in residence at the Europa Institute in Budapest and an IREX travel grant.

2. A recent overview overview stressing the role of Orthodoxy is Trond Gilberg, "Religion and Nationalism in Romania," in Religion and Nationalism in Soviet and East European Politics, ed. by Pedro Ramet (revised and expanded edition; Durham and London, 1989), 328-51. An informative but polemical contribution by Romania's leading church historian is Mircea Pacurariu, Pages from the History of the Romanian Church (The Uniatism in Transylvania) (Bucharest, 1991).

3. The tendency of the debate about indigenous and western elements in Romanian identity to reinforce national sentiment is the subject of a recent book by Katherine Verdery: National Ideology under Socialism. Identity and Cultural Politics in Ceausescu's Romania (Berkeley, Los Angeles, and Oxford, 1991). I have applied this argument to the Romanian religious rivalry (to which Verdery makes only one extended reference, pp. 32-3) in "Relaţiile interconfesionale şi procesul formării naţiunii române în Transilvania," forthcoming in Anuarul Institutului de Istorie Cluj 31 (1992).

4. The dichotomy is a recurrent theme in the works of Octavian Bârlea, the most prolific living historian of the Romanian Greek Catholics. See, for instance, his bilingual work Metropolia Bisericii Române Unite proclamă in 1855 la Blaj/Die Metropolie der Rumänischen Unierten Kirche verkändet im Jahre 1855 in Blaj (Munich, 1987).

5. The Hungarian thesis that the Romanian population rose drastically in the eighteenth century, rejected by Romanian historians, greatly affects our understanding of the early years of the church union. Zsolt Trócsányi used previously unknown sources to calculate that 350,000 Romanian Orthodox settled in Transylvania between 1712 and 1760 . If he is right, 
the economic policy of the Habsburgs undermined their religious one. See Trócsányi, "Új etnikai kép, új uralmi rendszer (1711-1770), " Erdély története II (Budapest, 1986), 975-81, and the most thorough Romanian refutation of the migration thesis by Prodan, Teoria imigratiei românilor din principatele române în Transilvania în veacul al XVIII-lea (Sibiu, 1944).

6. Konfession und Nation. Zur Frühgeschichte der serbischen und rumänischen Nationsbildung (Düsseldorf, 1977), and a Romanian critique by Miodrag Milin, "Interferenfe româno-sîrbe în secolul al XVIII-lea," Cultura si societate in in epoca moderna (ClujNapoca, 1990), 45-55.

7. Silviu Dragomir, Istoria desrobirei religioase a românilor din Ardeal în secolul XVIII, II (Sibiu, 1930), 284.

8. Keith Hitchins, The Idea of Nation. The Romanians of Transylvania, 1691-1849 (Bucharest, 1985), 83-84; Nicolae Albu, Istoria scolilor românesti din Transilvania între 1800-1867 (Bucharest, 1971), 23.

9. A concise statement of these writers' ideology is Radu Florescu, "The Uniate Church: Catalyst of Romanian National Consciousness," Slavonic and East European Review 45 (1967), 324-42.

10. The fundamental study of this movement is David Prodan, Supplex Libellus Valachorum or The Political Struggle of the Romanians in Transylvania during the Eighteenth Century (Bucharest, 1971).

11. Albu, 27.

12. The study of students' provenance, total number, and a list of $\mathbf{4 5 0}$ former students, are in Iacob Mârza, Şcoala şi natiune. Şcolile din Blaj in epoca renasterii nationale (ClujNapoca, 1987), 159-201. 
13. The quotation from Maior's book is in Pacurariu, 95. A recent investigation of the fate of the work is Károly Köllô, "Adalékok Gheorghe Sincai és Petru Maior mũveinek viszontságaihoz," Két irodalom mezsgyéjén (Bucharest, 1984), 114-22.

14. Bărnutiu's speech is republished, with a meticulous commentary by loan Chindriş, in Discursul de la Blaj si Scrieri de la 1848 (Cluj-Napoca, 1990). The italics are present in Chindriş' edition, which is based upon the original one of 1852 . See also Ladislau Gyémánt, Mişcarea nationala a românilor din Transilvania 1790-1848 (Bucharest, 1986), 166-73, and Bârlea, 122-51.

15. See Hitchins, Orthodoxy and Nationality. Andreiu Saguna and the Rumanians of Transylvania, 1846-1873 (Cambridge, 1977); and Turczynski, "Orthodoxe und Unierte, "Die Habsburgermonarchie 1848-1918 IV, Die Konfessionen (Vienna, 1985), 453-4. Şuluţiu developed these ideas at length in the manuscript "O serioasa cautare în trecutul şi viitorul naţiunii române," in Biblioteca Academiei Române, Cluj-Napoca, Ms. rom. 231.

16. Hitchins, Orthodoxy and Nationality, 123-4; Simion Retegan, Dieta româneasca a Transilvaniei (1863-1864) (Cluj-Napoca, 1979), 34-79. My calculation of voter participation is based on the Governor's report of July 31,1863 , preserved in the papers of the Transylvanian Court Chancellery, Budapest: Magyar Országos Levéltár. D228 1863-828.

17. Ioan Filip, "Il metropolita Alessandro Sterca Suluziu, " Societas Academica Dacoromana, Acta Historica 1 (1959), 83-99; I. Dumitriu-Snagov, Le Saint-Siège et la Roumanie Moderne 1850-1866 (Rome, 1982), 138-39, 204-13, with many valuable documents; and Niessen, "Metropolitan Alexandru Sterca-Sulutiu in the National Movement," Acta Universitatus Babes-Bólyai, Historia 32 (1987), 25-32. A new study by me examines this dispute in the light of the significance of ultramontanism for both nations: "Transylvanian Catholics and the Papacy in the Era of the Syllabus Errorum, " forthcoming in Hungarian Studies, 1993/94.

18. Hitchins, Idea of Nation, 144-6; János Mazsu, "A hazai értelmiség fejlôdésének nehány sajátossága a múlt század közepét követô évtizedekben, " Magyar történeti tanulmányok 17 (1984), 36. 
19. Mircea Păcurariu, Politica statului ungar fała de biserica românească din Transilvania în perioada dualismului 1867-1918 (Sibiu, 1986), 60-70; and Sándor Bíró, Kisebbségben és többségben. Románok és magyarok (1867-1940) (Bern, 1989), 106-28.

20. Mircea Păcurariu, Politica statului ungar, 100-101; and I. Dumitriu-Snagov, Le SaintSiège et la Roumanie Moderne 1866-1914 (Rome, 1989), 47-51.

21. Păcurariu explicitly ascribes the Romanians' "denationalization" to the Uniate Church (Politica statului ungar, 99-129). On the basis of census statistics and church records I have argued for the greater influence of the social environment in "Vallás és nemzetiség Erdélyben. Adalék Jászi Oszkár asszimiláció-elméletéhez," Regio 1991/3, 38-64.

22. Păcurariu, op. cit., 106-29; Dumitriu-Snagov, 1866-1914, 162-72 and numerous documents on 623-72 and 768-935; and Niessen, "Hungarians and Romanians in Habsburg and Vatican Diplomacy: The Creation of the Diocese of Hajdúdorog in 1912, " forthcoming in The Catholic Historical Review. My study examines the policy considerations that inspired the actions of Austro-Hungarian authorities and the Holy See. The fundamental history of the Hungarian Greek Catholics is István Pirigyi, A magyarországi görögkatolikusok története, 2 volumes (Nyíregyháza, 1990).

23. Peter Sugar, "The Problems of Nationalism in Eastern Europe Past and Present, " Wilson Center, Occasional Paper 13 (Washington, 1988), 6-8.

24. Biserica româna unita. Doua sute cinci zeci de ani de istorie (Madrid, 1952), 147.

25. The police report on the calugări from 1858 is cited in Eduard Weisenfeld, Die Geschichte der politische Publizistik bei den Siebenbürger Sachsen (Limburg an der Lahn, 1938), 82, while on August 9, 1862 (o.s.) Telegraful român, the Orthodox paper of Transylvania, reported the accusations against a nun by local officials.

26. Augustin Bunea, Discursuri, Autonomia bisericească, Diverse (Blas, 1903), 476-7. 
27. Paul Robert Magocsi, "Religion and Identity in the Carpathians," Cross Currents 7 (1988), 92.

28. The prominence of Orthodoxy in the new Romanian nationalism is a theme of my contribution, "Romanian Nationalism: An Ideology of Integration and Mobilization, " to the forthcoming East European Nationalism in the Twentieth Century, edited by Peter Sugar.

29. Biserica noastra si cultele minoritare. Marea discuffie parlamentare in jurul Legii Cultelor (Bucharest, 1928).

30. Hitchins, "Gîndirea: Nationalism in a Spiritual Guise," Social Change in Romania, 1860-1940 (Berkeley, 1978), 140 ff.; Alexander F. C. Webster, "The Romanian Legionary Movement. An Orthodox Christian Assessment of Anti-Semitism," The Carl Beck Papers in Russian and East European Studies \#502, Pittsburgh, 1986); and Armin Heinen, Die Legion "Erzengel Michael" in Rumänien. Soziale Bewegung und politische Organisation (Munich, 1986), 408-9.

31. [Chanoine] J. Georgesco, Une enquête sur l'Union des Églises en Roumanie (Lyon, 1939). The author was a Greek Catholic canon in Blaj.

32. Jenô Gergely, ed., A püspöki kar tanácskozásai. A magyar katolikus püspöki kar konferenciáinak jegyzôkönyveibôl 1919-1944 (Budapest, 1984); Alexandru Todea, "Naţionalismul Mitropolitului Nicolescu," Cultura creştină 21 (1941), 327-9; Silvestru A. Prunduş, "Vizite papale. Anticipări," Viafa creştină 2, 4 (February, 1991), 1.

33. An excellent account of the Greek Catholics under Communist rule is Janice Broun, "The Catholic Church in Romania," in Pedro Ramet, ed., Catholicism and Politics in Communist Societies (Durham and London, 1990), 207-31.

34. See Todea, "Persecution, Fear, and Freedom. The Greek Catholic Church in Rumania," in The Catholic Church in Eastern Europe. Persecution, Freedom, and Rebirth (Königstein, 1990), 36-48; and a long interview with him, "Ha ellenséged éhes, adj neki kenyeret!," 
Mérleg 26 (1990), 122-41; Cornea, "Scrisoarea adresată Sanctităţii Sale, Papa Ioan-Paul al II-lea," in Cornea, Scrisori deschise şi alte texte (Bucharest, 1991), 86-88.

35. The declaration is published in Kirche und Glaube in Rumänien (Munich, 1990), 123-6.

36. The text of the speech is in "A szentatya beszéde Máriapócson, "II. János Pál pápa magyarországi látogatása 1991. augusztus 16-20. A Szentatya beszédeinek magyar nyelvũ fordítása (second edition; Budapest, 1991), 28-33.

37. "Cardinalul Dr. Alexandru Todea în vizita arhiereasç la Cluj, " Viała creştină 2, 18 (September, 1991), 3.

38. Greek Catholic publications like the biweekly Viata cresting of Cluj have a tiny circulation. The most notable exception to the news blackout is the issue on the Greek Catholics of the Bucharest weekly Baricada 2, 29 (July 23, 1991). It includes an interview with Corneanu in which he criticizes Teoctist's remark. A good analysis of the dispute is Dan Ionescu, "The Orthodox-Uniate Conflict, " RFE/RL Research Institute, Report on Eastern Europe 2, 31 (August 2, 1991), 29-34.

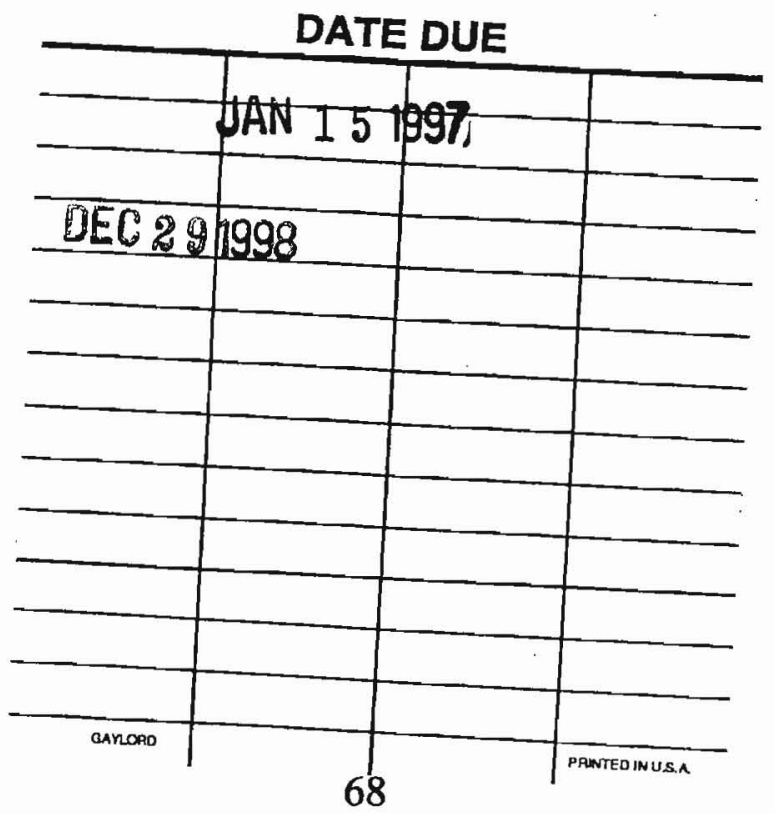

